\title{
Removal of phosphorus and nitrogen in sediments of the eutrophic Stockholm archipelago, Baltic Sea
}

\author{
Niels A. G. M. van Helmond ${ }^{1,2,3}$, , Elizabeth K. Robertson ${ }^{2,4}$, , Daniel J. Conley $^{2}$, Martijn Hermans ${ }^{1}$, \\ Christoph Humborg $^{5}$, L. Joëlle Kubeneck ${ }^{1, a}$, Wytze K. Lenstra ${ }^{1}$, and Caroline P. Slomp ${ }^{1}$ \\ ${ }^{1}$ Department of Earth Sciences, Faculty of Geosciences, Utrecht University, Princetonlaan 8a, \\ 3584 CB Utrecht, the Netherlands \\ ${ }^{2}$ Department of Geology, Lund University, Sölvegatan 12, 22362 Lund, Sweden \\ ${ }^{3}$ Department of Microbiology, Institute for Water and Wetland Research, Radboud University, Heyendaalseweg 135 , \\ 6525 AJ Nijmegen, the Netherlands \\ ${ }^{4}$ Department of Marine Sciences, University of Gothenburg, Box 461, 40530 Gothenburg, Sweden \\ ${ }^{5}$ Baltic Sea Centre, Stockholm University, 10691 Stockholm, Sweden \\ anow at: Institute of Biogeochemistry and Pollutant Dynamics, Department of Environmental Systems Science, \\ ETH Zürich, Universitätstrasse 16, 8092 Zürich, Switzerland \\ These authors contributed equally to this work.
}

Correspondence: Niels A. G. M. van Helmond (n.vanhelmond@uu.nl)

Received: 19 September 2019 - Discussion started: 7 October 2019

Revised: 20 April 2020 - Accepted: 21 April 2020 - Published: 24 May 2020

\begin{abstract}
Coastal systems can act as filters for anthropogenic nutrient input into marine environments. Here, we assess the processes controlling the removal of phosphorus (P) and nitrogen $(\mathrm{N})$ for four sites in the eutrophic Stockholm archipelago. Bottom water concentrations of oxygen $\left(\mathrm{O}_{2}\right)$ and $\mathrm{P}$ are inversely correlated. This is attributed to the seasonal release of $\mathrm{P}$ from iron-oxide-bound (Fe-oxidebound) $\mathrm{P}$ in surface sediments and from degrading organic matter. The abundant presence of sulfide in the pore water and its high upward flux towards the sediment surface $(\sim 4$ to $8 \mathrm{mmol} \mathrm{m}^{-2} \mathrm{~d}^{-1}$ ), linked to prior deposition of organic-rich sediments in a low- $\mathrm{O}_{2}$ setting ("legacy of hypoxia"), hinder the formation of a larger Fe-oxide-bound $\mathrm{P}$ pool in winter. This is most pronounced at sites where water column mixing is naturally relatively low and where low bottom water $\mathrm{O}_{2}$ concentrations prevail in summer. Burial rates of $\mathrm{P}$ are high at all sites $\left(0.03-0.3 \mathrm{~mol} \mathrm{~m}^{-2} \mathrm{yr}^{-1}\right)$, a combined result of high sedimentation rates $\left(0.5\right.$ to $\left.3.5 \mathrm{~cm} \mathrm{yr}^{-1}\right)$ and high sedimentary $\mathrm{P}$ at depth $\left(\sim 30\right.$ to $\left.50 \mu \mathrm{mol} \mathrm{g}^{-1}\right)$. Sedimentary $\mathrm{P}$ is dominated by Fe-bound $\mathrm{P}$ and organic $\mathrm{P}$ at the sediment surface and by organic $\mathrm{P}$, authigenic $\mathrm{Ca}-\mathrm{P}$ and detrital $\mathrm{P}$ at depth. Apart from one site in the inner archipelago, where a vivianite-type $\mathrm{Fe}(\mathrm{II})-\mathrm{P}$ mineral is likely present at depth,
\end{abstract}

there is little evidence for sink switching of organic or $\mathrm{Fe}$ oxide-bound $\mathrm{P}$ to authigenic $\mathrm{P}$ minerals. Denitrification is the major benthic nitrate-reducing process at all sites $(0.09$ to $1.7 \mathrm{mmol} \mathrm{m}^{-2} \mathrm{~d}^{-1}$ ) with rates decreasing seaward from the inner to outer archipelago. Our results explain how sediments in this eutrophic coastal system can remove $\mathrm{P}$ through burial at a relatively high rate, regardless of whether the bottom waters are oxic or (frequently) hypoxic. Our results suggest that benthic $\mathrm{N}$ processes undergo annual cycles of removal and recycling in response to hypoxic conditions. Further nutrient load reductions are expected to contribute to the recovery of the eutrophic Stockholm archipelago from hypoxia. Based on the dominant pathways of $\mathrm{P}$ and $\mathrm{N}$ removal identified in this study, it is expected that the sediments will continue to remove part of the $\mathrm{P}$ and $\mathrm{N}$ loads.

\section{Introduction}

Anthropogenic activities are altering coastal marine ecosystems worldwide (Jackson et al., 2001; Halpern et al., 2008; Diaz and Rosenberg, 2008). Excessive inputs of the nutrients phosphorus $(\mathrm{P})$ and nitrogen $(\mathrm{N})$, primarily derived from 
agricultural activities and wastewater, have led to widespread eutrophication, particularly in coastal areas (e.g., Nixon et al., 1996; Smith, 2003; Rabalais et al., 2009). Besides increased marine primary productivity, often in the form of harmful algal blooms (Anderson et al., 2003), eutrophication results in depletion of bottom water oxygen $\left(\mathrm{O}_{2}\right)$, as a result of increased $\mathrm{O}_{2}$ consumption upon degradation of organic material (Diaz and Rosenberg, 2008; Rabalais et al., 2010).

Restoration of coastal ecosystems requires a reduction in eutrophication (e.g., Boesch, 2002). However, simply decreasing nutrient loading often does not render the desired effect because of nonlinearities in the response of coastal ecosystems to changes in nutrient loading (Duarte et al., 2009; Kemp et al., 2009; Carstensen et al., 2011). Much of this behavior is due to recycling of nutrients from the seafloor and the $\mathrm{O}_{2}$ demand created by the historical deposition of organic-rich sediments ("legacy of hypoxia"; Conley et al., 2002; Turner et al., 2008; Hermans et al., 2019a). In addition, cyanobacteria, which are frequently present in eutrophic systems, can biologically fix atmospheric $\mathrm{N}\left(\mathrm{N}_{2}\right)$, thereby sustaining eutrophication (e.g., Paerl and Otten, 2013).

Coastal systems also act as temporary and permanent sinks for nutrients and as filters for adjacent marine environments (e.g., Cloern, 2001; McGlathery et al., 2007; Bouwman et al., 2013). In brief, coastal environments can lead to the following: (1) transformation of nutrients, changing their chemical form, e.g., from dissolved to particulate and from inorganic to organic; (2) the retention of nutrients, i.e., delaying the nutrient flow from terrestrial to marine environments by incorporating nutrients into biomass or abiotic particles; and (3) the removal of nutrients, i.e., the permanent direction of nutrients out of the ecosystem (Asmala et al., 2017). The filtering capacity of coastal systems depends on a variety of biological, physical and chemical parameters, such as the concentrations of nutrients and dissolved $\mathrm{O}_{2}$ (McGlathery et al., 2007), the presence and type of flora and fauna (Norkko et al., 2012; Krause-Jensen and Duarte, 2016), the type of coastal system and underlying sediment (Asmala et al., 2017), wind, tides, and the water residence time (Nixon et al., 1996; Josefson and Rasmussen, 2000). This can lead to a wide variety of removal rates for $\mathrm{P}$ and $\mathrm{N}$ in different types of coastal environments (Asmala et al., 2017, 2019).

Most removal of $\mathrm{P}$ in coastal systems takes place through burial in fine-grained sediments. The main $\mathrm{P}$ burial phases are as follows: (1) P associated with organic matter, (2) P bound to iron (Fe) (oxyhydr)oxides (henceforth termed $\mathrm{Fe}$ oxides) and (3) $\mathrm{P}$ in authigenic carbonate fluorapatite (Ruttenberg and Berner, 1993; Slomp et al., 1996). Recent work has shown that $P$ may also be sequestered in the form of vivianite-type $\mathrm{Fe}$ (II)-phosphate minerals, particularly in lowsalinity environments with high inputs of Fe oxides (e.g., Egger et al., 2015). Burial of $P$ is redox sensitive, with retention of $\mathrm{P}$ bound to $\mathrm{Fe}$ oxides and in organic matter decreasing upon increased hypoxia and anoxia (e.g., Van Cappellen and Ingall, 1994). However, a more limited exposure to $\mathrm{O}_{2}$ also enhances the preservation of organic matter and may allow organic $\mathrm{P}$ to become the dominant form of $\mathrm{P}$ in the sediment (Lukkari et al., 2009; Mort et al., 2010; Slomp, 2011).

Fixed $\mathrm{N}$ can be removed via multiple pathways: (1) denitrification, (2) anaerobic ammonium $\left(\mathrm{NH}_{4}^{+}\right)$oxidation (anammox) and (3) burial in sediments. Burial of $\mathrm{N}$ generally only represents a small fraction of the total $\mathrm{N}$ removed (e.g., Gustafsson et al., 2012; Almroth-Rosell et al., 2016). In coastal systems, benthic denitrification is generally the dominant pathway for N removal (e.g., Seitzinger, 1990; Dalsgaard et al., 2005). However, dissimilatory nitrate $\left(\mathrm{NO}_{3}^{-}\right)$ reduction to ammonium (DNRA) also competes for $\mathrm{NO}_{3}^{-}$ in sediments and reduces $\mathrm{NO}_{3}^{-}$to $\mathrm{NH}_{4}^{+}$, thereby potentially contributing to internal $\mathrm{N}$ recycling (Thamdrup, 2012; Giblin et al., 2013). Field, laboratory and modeling studies have indicated that DNRA may dominate over $\mathrm{N}$ removal when $\mathrm{NO}_{3}^{-}$is limited (e.g., Algar and Vallino, 2014; Kraft et al., 2014; Kessler et al., 2018), which frequently occurs during bottom water hypoxia (e.g., Christensen et al., 2000; Nizzoli et al., 2010; Jäntti and Hietanen, 2012). Thus, the partitioning between $\mathrm{N}$ removal $\left(\mathrm{as}_{2}\right.$ ) from the ecosystem and transformation of organic $\mathrm{N}$ to $\mathrm{NH}_{4}^{+}$, which can be retained in the ecosystem, may be strongly influenced by eutrophic conditions.

Predictions of the response of coastal areas to decreased nutrient inputs and/or natural or artificial reoxygenation require insight into the processes responsible for $\mathrm{P}$ and $\mathrm{N}$ cycling and whether $\mathrm{P}$ and $\mathrm{N}$ are transformed, retained or removed. This is of particular relevance to the coastal zone of the Baltic Sea because of its highly eutrophic and frequently low- $\mathrm{O}_{2}$ state (Conley et al., 2011). Active nutrient reductions from the 1980s onward (Gustafsson et al., 2012) are now leading to the first signs of recovery in the region (Andersen et al., 2017), although not yet in the Baltic Proper (e.g., Hansson et al., 2019). A good example of a recovering coastal system within the Baltic Sea is the Stockholm archipelago (Karlsson et al., 2010), where, based on modeling, recovery from hypoxia was suggested to be potentially associated with the buildup of a pool of Fe-oxide-bound P in surface sediments driven by increased macrofaunal activity (Norkko et al., 2012). However, this mechanism would not lead to increased permanent $\mathrm{P}$ burial and hence, by itself, would not lead to long-term recovery of the system ( $>5-10$ years). Based on coupled physical and biogeochemical models it was recently suggested that the Stockholm archipelago was very efficient in removing $\mathrm{P}$ and $\mathrm{N}$ for the period 19902012, accounting for a loss of $65 \%$ of the land-derived P input and $75 \%$ of the land-derived and atmospheric $\mathrm{N}$ input (Almroth-Rosell et al., 2016). The area-specific P and $\mathrm{N}$ retention was highest in the inner part of the Stockholm archipelago. Based on the high $\mathrm{NO}_{3}^{-}$concentrations in the bottom water, and high organic carbon contents in the sediment in the archipelago, benthic denitrification is expected to dominate $\mathrm{N}$ removal (Almroth-Rosell et al., 2016; Asmala et al., 2017). Recent mass balance modeling for the inner 


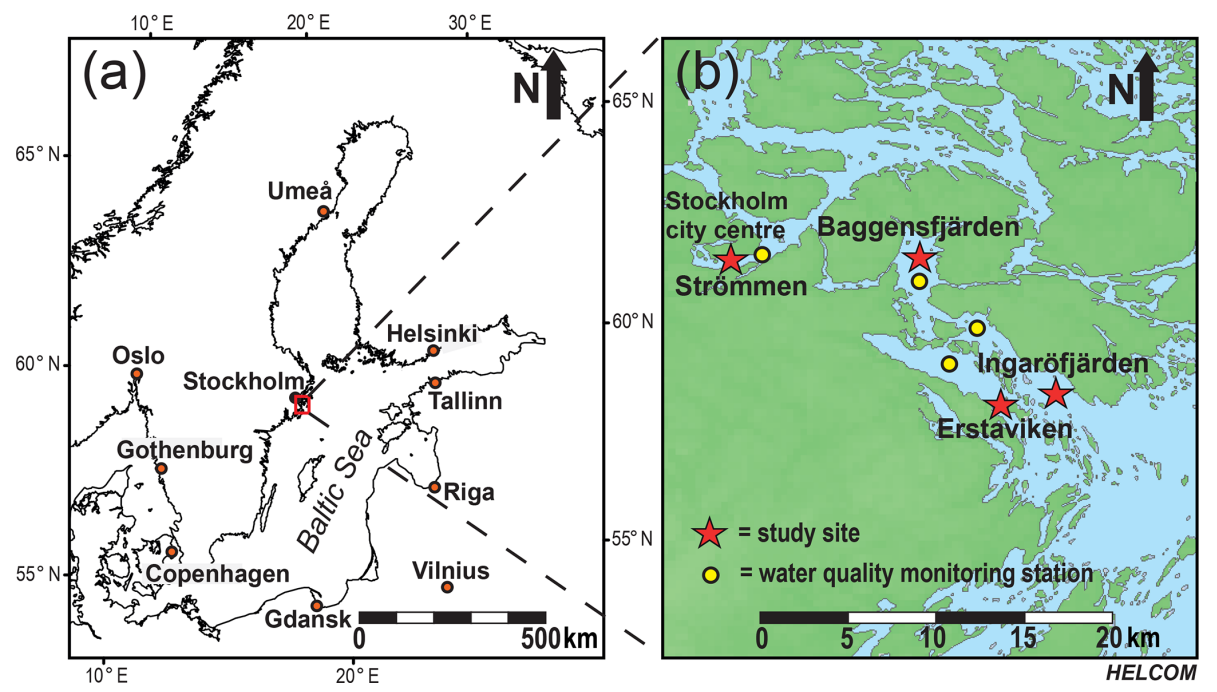

Figure 1. The Baltic Sea (Ning et al., 2016), with the study area in the Stockholm archipelago indicated by the red box (a). Detailed map of the southwestern part of the inner and intermediate Stockholm archipelago (see Almroth-Rosell et al., 2016). Red stars indicate the locations of the study sites: Strömmen, Baggensfjärden, Erstaviken and Ingaröfjärden. Yellow dots indicate the locations of the water quality monitoring stations (SMHI, 2019) most proximate to the sites in this study (b).

archipelago suggests that sediments are a $\mathrm{P}$ sink in winter and a source in summer and autumn, with low annual net retention in the sediments (Walve et al., 2018). These apparently conflicting results between different modeling approaches emphasize the need to better understand and quantify $\mathrm{P}$ removal, i.e., permanent burial of $\mathrm{P}$ in the sediment.

The objectives of this study are to identify and quantify the main $\mathrm{P}$ burial phases and the processes controlling removal of $\mathrm{N}$ in sediments of the Stockholm archipelago. We present geochemical depth profiles for a range of sediment components ( $\mathrm{P}, \mathrm{Fe}$, organic carbon) and rate measurements of benthic $\mathrm{N}$ cycling processes for four sites along a gradient from the inner archipelago towards the open Baltic Sea. These sites capture a range of bottom water $\mathrm{O}_{2}$ concentrations from seasonally hypoxic and occasionally euxinic to oxic. Our results highlight the key processes in sediments in eutrophic coastal systems that lead to removal of $\mathrm{P}$ and $\mathrm{N}$ and that may prevent their further transport to the marine environment.

\section{Materials and methods}

\subsection{Study area}

The Stockholm archipelago covers $\sim 5000 \mathrm{~km}^{2}$; is formed by (post)glacial processes; and consists of approximately 30000 mostly rocky islands that are surrounded by a network of basins and straits of different shapes, sizes and depths (Hill and Wallström, 2008). Based on the connections and rates of water exchange between the different basins and the open Baltic Sea, the Stockholm archipelago can be divided into an inner, intermediate and outer archipelago (Almroth-Rosell et al., 2016). The Norrström river connects the Stockholm archipelago to its main freshwater source, Lake Mälaren, which, on average, discharges about $160 \mathrm{~m}^{3} \mathrm{~s}^{-1}$ of freshwater into the most western part of the archipelago in central Stockholm (Lindh, 2013). As a consequence, surface waters in this part of the archipelago are nearly freshwater, whereas those in the outer archipelago have an average salinity of $\sim 7$ because of input of brackish water from the open Baltic Sea (Engqvist and Andrejev, 2003; Hill and Wallström, 2008). Particularly in the inshore parts of the archipelago, a (weak) halocline develops due to the differences in salinity between the (nearly) fresh surface water and the underlying more saline water. In the summer, water column stratification is more pronounced and widespread due to the development of a thermocline. However, in the more open parts of the archipelago, wind-driven mixing may interrupt stratification (Gidhagen, 1987).

The average annual nutrient input into the Stockholm archipelago was $217 \mathrm{tP}$ and $8288 \mathrm{tN}$ for the period 1990 2012 , of which approximately $174 \mathrm{tP}$ and $5846 \mathrm{tN}$ entered the inner archipelago via the Norrström river (AlmrothRosell et al., 2016). This high nutrient load mostly originates from wastewater treatment facilities of Stockholm (Johansson and Wallström, 2001) and, in combination with (seasonal) stratification of the water column, has led to widespread eutrophication in the past. As a result, large parts of the Stockholm archipelago are or have been (seasonally) hypoxic to euxinic over the past century (Jonsson et al., 1990; Conley et al., 2011). Studies have shown decreases in dissolved inorganic $\mathrm{P}$ and total $\mathrm{P}$ due to reductions in nutrient inputs from sewage treatment plants (Walve et al., 2018), and indications of environmental recovery have been deduced 


\section{Bottom water conditions \\ (1998-2017)}

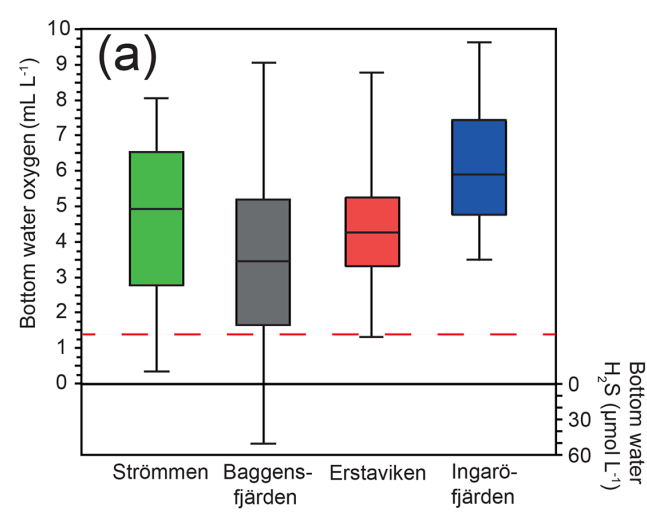

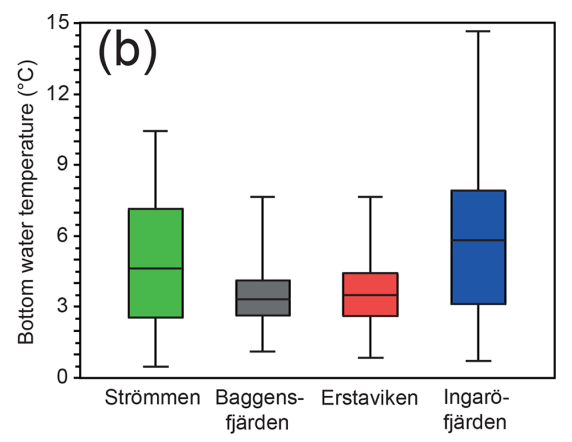

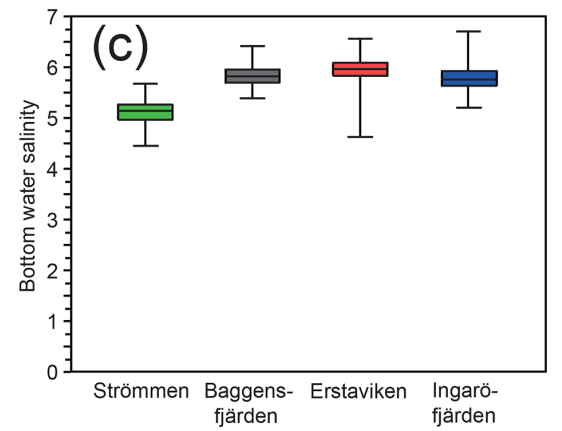

Figure 2. Ranges in bottom water oxygen and sulfide (a), temperature (b) and salinity (c) over the last 20 years (1998-2017) at water quality monitoring stations (SMHI, 2019; Fig. 1) most proximate to the study sites. The solid line between the boxes is the median, and the boxes represent the second and third quartiles. The error bars indicate the minimum and maximum value recorded for the displayed period. The dashed red line (located at $1.4 \mathrm{~mL} \mathrm{~L}^{-1}$; Fig. 2a) indicates the hypoxic boundary.

from visual observations of sediment cores (Karlsson et al., 2010).

\subsubsection{Study sites}

For this study, sediments and bottom water from four different locations in the inner and intermediate part of the Stockholm archipelago (see Almroth-Rosell et al., 2016; Fig. 1) were collected. The study sites are located in the basins Strömmen (central Stockholm), Baggensfjärden, Erstaviken and Ingaröfjärden and are characterized by a range of water depths and bottom water redox conditions (Figs. 2, S1 (in the Supplement); Table 1). Strömmen is located most proximately to the outlets of the sewage treatment plants close to the center of Stockholm, which presumably contributes to the relatively high total $\mathrm{P}$ concentrations in the bottom water (Fig. 3a). Baggensfjärden is the most restricted basin in this study (i.e., landlocked with narrow and relatively shallow connections to adjacent basins), leading to reduced water column mixing, culminating in low- $\mathrm{O}_{2}$ bottom waters annually in summer. Erstaviken and Ingaröfjärden have a more open connection with the Baltic Proper, leading to better water column mixing. Ingaröfjärden is the least restricted basin in this study and subsequently the most consistently well-oxygenated basin throughout the year. Extensive water quality monitoring of the study area (obtained from the SHARK database at http://www.smhi.se/klimatdata/oceanografi/havsmiljodata/ marina-miljoovervakningsdata, last access: 10 April 2019; Swedish Meteorological and Hydrological Institute - SMHI, 2019) shows a clear inverse correlation between bottom water $\mathrm{O}_{2}$ concentrations and $\mathrm{P}$ and a positive correlation between bottom water $\mathrm{O}_{2}$ and N/P ratios (Fig. 3a, b). Bottom water $\mathrm{O}_{2}$ and nutrient concentrations follow a distinct annual pattern, with maximum $\mathrm{O}_{2}$ and minimum nutrient concentrations in winter. After winter, $\mathrm{O}_{2}$ gradually drops and nutrient concentrations gradually increase, reaching minimum and maximum values at the end of summer and in autumn, respectively, followed by a reset of the system (Fig. 3c, d). The difference in amplitude of the changes in $\mathrm{O}_{2}$ and total $\mathrm{P}$ concentrations between sites is likely the combined effect of differences in water column mixing and in recycling of $\mathrm{P}$ from the sediment associated with changes in bottom water $\mathrm{O}_{2}$.

\subsection{Sampling}

Sediment cores were collected with R/V Electra in March 2017. Prior to coring, a CTD (Sea-Bird 911plus), equipped with a circular rosette of Niskin bottles $(12 \times 5 \mathrm{~L})$, was deployed to determine key water column characteristics at the time of sampling, such as dissolved $\mathrm{O}_{2}$ concentrations, temperature and salinity (Table 2), and to collect bottom water. At each site, $\sim 20$ Gemini cores (two cores per cast; $\varnothing=8 \mathrm{~cm}$; between 40 and $60 \mathrm{~cm}$ of sediment and $>$ $10 \mathrm{~cm}$ of overlying water) were collected for analysis of 

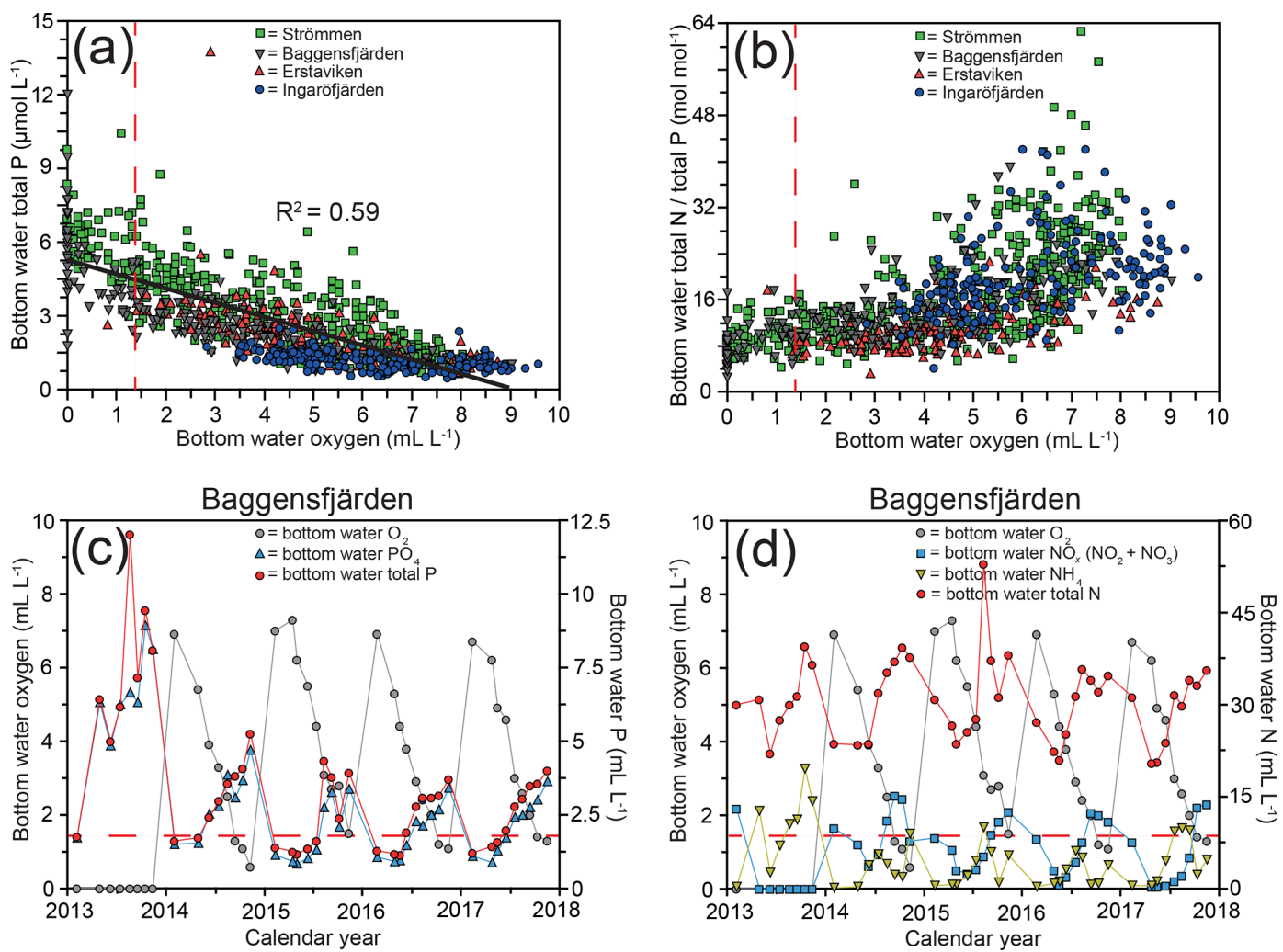

Figure 3. Bottom water dissolved oxygen plotted against total $P$, with the black line depicting the inverse linear relationship between the two (a) and total N / total P (b) for the water quality monitoring stations (SMHI, 2019; Fig. 1) most proximate to the study sites. Bottom water dissolved oxygen and bottom water $\mathrm{P}(\mathbf{c})$ and $\mathrm{N}(\mathbf{d})$ for Baggensfjärden from 2013 until 2017. The dashed red line (located at $1.4 \mathrm{~mL} \mathrm{~L}^{-1}$ ) indicates the hypoxic boundary in all panels.

Table 1. General study site characteristics.

\begin{tabular}{|c|c|c|c|c|}
\hline & Strömmen & Baggensfjärden & Erstaviken & Ingaröfjärden \\
\hline Coordinates & $59^{\circ} 19^{\prime} 09^{\prime \prime} \mathrm{N}$ & $59^{\circ} 18^{\prime} 36^{\prime \prime} \mathrm{N}$ & $59^{\circ} 13^{\prime} 06^{\prime \prime} \mathrm{N}$ & $59^{\circ} 13^{\prime} 20^{\prime \prime} \mathrm{N}$ \\
\hline$\left(\mathrm{DD}^{\circ} \mathrm{MM}^{\prime} \mathrm{SS}^{\prime \prime}\right)$ & $18^{\circ} 07^{\prime} 09^{\prime \prime} \mathrm{E}$ & $18^{\circ} 19^{\prime} 24^{\prime \prime} \mathrm{E}$ & $18^{\circ} 23^{\prime} 42^{\prime \prime} \mathrm{E}$ & $18^{\circ} 27^{\prime} 01^{\prime \prime} \mathrm{E}$ \\
\hline Water depth (m) & 30 & 40 & 68 & 37 \\
\hline $\begin{array}{l}\text { Bottom water } \\
\text { redox conditions }{ }^{a}\end{array}$ & $\begin{array}{l}\text { Seasonally } \\
\text { hypoxic }\end{array}$ & $\begin{array}{l}\text { Seasonally hypoxic } \\
\text { Sometimes euxinic }\end{array}$ & $\begin{array}{l}\text { Sporadically } \\
\text { hypoxic }\end{array}$ & Oxic \\
\hline $\begin{array}{l}\text { Location in the } \\
\text { archipelago } b\end{array}$ & Inner & Intermediate & Intermediate & Intermediate \\
\hline
\end{tabular}

a Bottom water redox conditions based on monitoring data (SMHI, 2019). ${ }^{\mathrm{b}}$ Following the classification by Almroth-Rosell et al. (2016).

methane $\left(\mathrm{CH}_{4}\right)$, high-resolution microelectrode depth profiling, (anoxic) sediment and pore water collection, $\mathrm{N}_{2}$ slurry and incubation experiments, and sieving for macrofauna (Table 2).

Samples for $\mathrm{CH}_{4}$ analysis were taken directly after coring via predrilled holes (taped prior to coring) in the Gemini core liner with a depth spacing of $2.5 \mathrm{~cm}$ as described in Lenstra et al. (2018).
High-resolution $(50 \mu \mathrm{m})$ depth profiles of dissolved $\mathrm{O}_{2}$ were obtained from one core per site, using microelectrodes (Unisense A/S, Denmark), as described in Hermans et al. (2019b). The diffusive uptake of $\mathrm{O}_{2}$ was determined by numerical modeling with PROFILE (Berg et al., 1998) using the high-resolution $\mathrm{O}_{2}$ measurements.

For anoxic sediment and pore water collection, one core was sliced in a $\mathrm{N}_{2}$-filled glove bag. Two bottom water samples were taken from the overlying water after which the core 
Table 2. Key site characteristics at time of sampling (March 2017).

\begin{tabular}{lrrrr}
\hline & Strömmen & Baggensfjärden & Erstaviken & Ingaröfjärden \\
\hline Bottom water $\mathrm{O}_{2}\left(\mathrm{~mL} \mathrm{~L}^{-1}\right)$ & 7.6 & 7 & 6.7 & 8.5 \\
$\mathrm{O}_{2}$ penetration depth* $(\mathrm{mm})$ & 2.1 & 1.9 & 3.6 & 18 \\
Diffusive uptake of $\mathrm{O}_{2}\left(\mathrm{mmol} \mathrm{m}^{-2} \mathrm{~d}^{-1}\right)$ & 13.4 & 13.8 & 7.3 & 3.1 \\
Bottom water salinity & 5.2 & 6.2 & 6.4 & 6.2 \\
Bottom water temperature $\left({ }^{\circ} \mathrm{C}\right)$ & 1.5 & 2.4 & 2.2 & 1.3 \\
Sediment type & Mud & Mud & Mud & Bioturbated mud \\
Suboxic zone* $(\mathrm{mm})$ & 4 & - & 15 & 25 \\
Macrofauna & None & None & None & Marenzelleria \\
\hline
\end{tabular}

* Derived from high-resolution microelectrode profiling (Fig. S3).

was sliced at a resolution of $0.5 \mathrm{~cm}(0$ to $10 \mathrm{~cm}), 2 \mathrm{~cm}(10$ to $20 \mathrm{~cm}), 4 \mathrm{~cm}(20$ to $40 \mathrm{~cm})$ and $5 \mathrm{~cm}$ until reaching the bottom of the core. The sediment was centrifuged (in $50 \mathrm{~mL}$ tubes) at $3500 \mathrm{rpm}$ for $20 \mathrm{~min}$ to extract pore water. The sediment remaining after centrifugation was stored in $\mathrm{N}_{2}$-flushed gas-tight aluminum bags at $-20^{\circ} \mathrm{C}$ until further analysis. Bottom and pore water samples were filtered over a $0.45 \mu \mathrm{m}$ filter in a $\mathrm{N}_{2}$-filled glove bag. Subsamples were taken for (1) $\mathrm{H}_{2} \mathrm{~S}$ analysis $(0.5 \mathrm{~mL}$ was added to $2 \mathrm{~mL}$ of $2 \%$ zinc (Zn) acetate); (2) analysis of dissolved $\mathrm{Fe}$ and $\mathrm{P}(1 \mathrm{~mL}$ was acidified with $10 \mu \mathrm{L}$ of $30 \%$ Suprapur $\mathrm{HCl}$ ); and (3) analysis of sulfate $\left(\mathrm{SO}_{4}^{2-} ; 0.5 \mathrm{~mL}\right)$, and stored at $4{ }^{\circ} \mathrm{C}$. Subsamples for $\mathrm{N}$ oxides $\left(\mathrm{NO}_{x}=\mathrm{NO}_{3}^{-}+\right.$nitrite $\left.\left(\mathrm{NO}_{2}^{-}\right) ; 1 \mathrm{~mL}\right)$ and $\mathrm{NH}_{4}^{+}$ $(1 \mathrm{~mL})$ were stored at $-20^{\circ} \mathrm{C}$.

At Strömmen, one core was sliced at the same resolution as described above to determine porosity and ${ }^{210} \mathrm{~Pb}$. Data for porosity and ${ }^{210} \mathrm{~Pb}$ for the other three study sites were taken from van Helmond et al. (2020).

\subsection{Bottom and pore water analysis}

Concentrations of $\mathrm{CH}_{4}$ were determined with a Thermo Finnigan trace gas chromatograph equipped with a flame ionization detector as described by Lenstra et al. (2018). The average analytical uncertainty based on duplicates and triplicates was $<5 \%$. Pore water $\mathrm{H}_{2} \mathrm{~S}$ was determined spectrophotometrically using phenylenediamine and ferric chloride (Cline, 1969). Upward fluxes of $\mathrm{H}_{2} \mathrm{~S}$ in the pore water towards the sediment surface were calculated as detailed in Hermans et al. (2019a). Dissolved Fe and P (assumed to be present as $\mathrm{Fe}^{2+}$ and $\mathrm{HPO}_{4}^{2-}$ ) were measured by inductively coupled plasma optimal emission spectroscopy (ICPOES; SPECTRO ARCOS). Nitrogen oxides (Schnetger and Lehners, 2014) and $\mathrm{NO}_{2}^{-}$(Grasshoff et al., 1999) were determined colorimetrically. Concentrations of $\mathrm{NO}_{3}^{-}$were calculated from the difference between $\mathrm{NO}_{x}$ and $\mathrm{NO}_{2}^{-}$concentrations. Ammonium was determined colorimetrically using indophenol blue (Solorzano, 1969). Concentrations of $\mathrm{SO}_{4}^{2-}$ were determined by ion chromatography. The average analytical uncertainty based on duplicates was $<1 \%$.

\subsection{Solid-phase analysis}

All sediment samples were freeze-dried, powdered and homogenized using an agate mortar and pestle in an argon-filled glove box. Prior to analysis, samples were split into oxic and anoxic fractions (i.e., samples stored open to air and in a $\mathrm{N}_{2}$ or argon atmosphere).

\subsubsection{Total elemental composition}

Approximately $125 \mathrm{mg}$ of the oxic sediment split was digested in a mixture of strong acids as described by van Helmond et al. (2018). The residues were dissolved in $1 \mathrm{MHNO}_{3}$ and analyzed for their elemental composition by ICP-OES. Average analytical uncertainty based on duplicates and triplicates was $<5 \%$ for calcium $(\mathrm{Ca})$ and $<3 \%$ for $\mathrm{P}$. The calcium carbonate content $\left(\mathrm{CaCO}_{3} \mathrm{wt} \%\right)$ was calculated based on the Ca content measured by ICP-OES, assuming that all $\mathrm{Ca}$ was in the form of $\mathrm{CaCO}_{3}$.

\subsubsection{Organic carbon and nitrogen}

Between 200 and $300 \mathrm{mg}$ of the oxic sediment split was decalcified using $1 \mathrm{M} \mathrm{HCl}$ as described by van Helmond et al. (2018), after which dried and repowdered residues were analyzed for their carbon and nitrogen content with a Fisons Instruments NA 1500 NCS analyzer. Average analytical uncertainty based on duplicates was $<2 \%$ for carbon and $<3 \%$ for nitrogen. Organic carbon $\left(\mathrm{C}_{\text {org }}\right)$ and organic nitrogen $\left(\mathrm{N}_{\text {org }}\right)$ contents were calculated after a correction for the weight loss upon decalcification and the salt content of the freeze-dried sediment. For Baggensfjärden, Erstaviken and Ingaröfjarden, $\mathrm{C}$ and $\mathrm{N}$ contents were taken from van Helmond et al. (2020).

\subsubsection{Sequential extraction of iron}

Between 50 and $100 \mathrm{mg}$ of the anoxic sediment split was subjected to a sequential extraction procedure based on a combination of the procedures by Poulton and Canfield (2005) and Claff et al. (2010) to determine the different phases of sedimentary Fe (Kraal et al., 2017). Briefly, under $\mathrm{O}_{2}$-free 
conditions (1) $10 \mathrm{~mL}$ of $1 \mathrm{M} \mathrm{HCl}, \mathrm{pH} 0$, was added to extract $(4 \mathrm{~h}) \mathrm{Fe}$ (II) and $\mathrm{Fe}$ (III) minerals such as easily reducible $\mathrm{Fe}$ oxides (e.g., ferrihydrite and lepidocrocite), $\mathrm{Fe}$ carbonates and $\mathrm{Fe}$ monosulfides; (2) $10 \mathrm{~mL}$ of $0.35 \mathrm{M}$ acetic acid, $0.2 \mathrm{MNa}_{3}$ citrate and $50 \mathrm{~g} \mathrm{~L}^{-1} \mathrm{Na}$ dithionite, $\mathrm{pH} 4.8$, was added to extract $(4 \mathrm{~h})$ crystalline Fe-oxide minerals such as goethite and hematite; (3) $10 \mathrm{~mL}$ of $0.17 \mathrm{M}$ ammonium oxalate and $0.2 \mathrm{M}$ oxalic acid, $\mathrm{pH} 3.2$, was added to extract $(6 \mathrm{~h})$ recalcitrant oxide minerals such as magnetite; and (4) $10 \mathrm{~mL}$ of $65 \% \mathrm{HNO}_{3}$ was added to extract $(2 \mathrm{~h})$ pyrite $\left(\mathrm{FeS}_{2}\right)$. For all extracts, Fe concentrations were determined colorimetrically with the phenanthroline method, adding hydroxylamine hydrochloride as a reducing agent to convert all $\mathrm{Fe}^{3+}$ into $\mathrm{Fe}^{2+}$ (APHA, 2005). For the first step the absorbance before and after addition of the reducing agent was measured, in order to separate $\mathrm{Fe}^{2+}$ and $\mathrm{Fe}^{3+}$. The $\mathrm{Fe}$ concentrations of the $\mathrm{Fe}^{3+}$ fraction of the first step and the second step were summed and are henceforth referred to as Fe oxides. Average analytical uncertainty based on duplicates and triplicates was $<10 \%$ for all fractions.

\subsubsection{Sequential extraction of sulfur}

Approximately $300 \mathrm{mg}$ of the anoxic sediment split was subjected to a sequential extraction procedure (Burton et al., 2008) to determine sedimentary sulfur phases. Briefly, under $\mathrm{O}_{2}$-free conditions (1) $10 \mathrm{~mL}$ of $6 \mathrm{M} \mathrm{HCl}$ and $2 \mathrm{~mL}$ of $0.1 \mathrm{M}$ ascorbic acid were added to dissolve acid-volatile sulfur (AVS, assumed to represent $\mathrm{Fe}$ monosulfides - FeS), and the released $\mathrm{H}_{2} \mathrm{~S}$ was trapped in a tube filled with $7 \mathrm{~mL}$ of alkaline zinc acetate solution $(24 \mathrm{~h})$ and (2) $10 \mathrm{~mL}$ of acidic chromium(II) chloride was added to dissolve chromiumreducible sulfur (CRS, assumed to represent $\mathrm{FeS}_{2}$ ), and the released $\mathrm{H}_{2} \mathrm{~S}$ was trapped in a tube filled with $7 \mathrm{~mL}$ of alkaline zinc acetate solution $(48 \mathrm{~h})$. For both fractions, the amount of sulfur in the zinc sulfide precipitates was determined by iodometric titration (APHA, 2005). Average analytical uncertainty, based on duplicates, was $<7 \%$ for both AVS and CRS.

\subsubsection{Sequential extraction of phosphorus}

Approximately $100 \mathrm{mg}$ of the anoxic sediment split was subjected to a sequential extraction procedure following the procedure of Ruttenberg (1992), modified by Slomp et al. (1996), but including the exchangeable $\mathrm{P}$ step. Briefly, under $\mathrm{O}_{2}$-free conditions (1) $10 \mathrm{~mL}$ of $1 \mathrm{M} \mathrm{MgCl}_{2}, \mathrm{pH} \mathrm{8}$, was added to extract ( $0.5 \mathrm{~h}$ ) exchangeable P (Exch. P); (2) $10 \mathrm{~mL}$ of $0.3 \mathrm{M} \mathrm{Na}_{3}$ citrate, $1 \mathrm{M} \mathrm{NaHCO}_{3}$ and $25 \mathrm{~g} \mathrm{~L}^{-1} \mathrm{Na}$ dithionite (CDB), $\mathrm{pH} 7.6$, was added after which $10 \mathrm{~mL}$ of $1 \mathrm{M} \mathrm{MgCl}_{2}$, pH 8, was added, together extracting (8 and $0.5 \mathrm{~h}$, respectively) the P-bound-to-Fe fraction, including Feoxide-bound $\mathrm{P}$ and vivianite (Fe-bound P; Nembrini et al., 1983; Dijkstra et al., 2014); (3) $10 \mathrm{~mL}$ of $1 \mathrm{MNa}$ acetate buffered to $\mathrm{pH} 4$ with acetic acid was added after which
$10 \mathrm{~mL}$ of $1 \mathrm{M} \mathrm{MgCl}_{2}, \mathrm{pH} 8$, was added, together extracting (6 and $0.5 \mathrm{~h}$, respectively) authigenic Ca-P, including carbonate fluorapatite, hydroxyapatite and carbonate-bound $\mathrm{P}$ (Auth. P); (4) $10 \mathrm{~mL}$ of $1 \mathrm{M} \mathrm{HCl}, \mathrm{pH} \mathrm{0,} \mathrm{was} \mathrm{added} \mathrm{to} \mathrm{ex-}$ tract (24h) P in detrital minerals (Detr. P); and (5) ashing of the residue at $550^{\circ} \mathrm{C}(2 \mathrm{~h})$ after which $10 \mathrm{~mL}$ of $1 \mathrm{M} \mathrm{HCl}$, $\mathrm{pH} 0$, was added to extract (24h) $\mathrm{P}$ in organic matter (Org. $\mathrm{P})$. The $\mathrm{P}$ content in the citrate-dithionite-bicarbonate extract was analyzed by ICP-OES. All other solutions were measured colorimetrically (Strickland and Parsons, 1972). Average analytical uncertainty, based on duplicates, was $<7 \%$ for all fractions. Total $\mathrm{P}$ derived from acid digestion and subsequent ICP-OES analyses was on average within $5 \%$ of the summed $\mathrm{P}$ fractions derived from the sequential extraction.

\subsection{Sediment nitrogen cycling}

\subsubsection{Incubations of ${ }^{15} \mathrm{~N}$}

Rates of benthic $\mathrm{NO}_{3}^{-}$-reducing pathways were determined using the whole-core isotope pairing technique (IPT) and parallel slurry incubations (Nielsen, 1992; Risgaard-Petersen et al., 2003). Bottom water from Niskin bottles collected at each site was used to fill the incubation chamber (approx. $30 \mathrm{~L}$ ) and maintained at in situ $\mathrm{O}_{2}$ concentrations using compressed air and nitrogen gas mixtures. Small core liners $(\varnothing 2.5 \mathrm{~cm})$ were used to take subcores from the Gemini cores and were immediately transferred to the incubation tank so that all cores were submerged and stoppers were removed. Sodium ${ }^{15} \mathrm{~N}$-nitrate solution $\left(\mathrm{Na}^{15} \mathrm{NO}_{3}, 98\right.$ atom \% ${ }^{15} \mathrm{~N}$, Sigma Aldrich, final concentration $\sim 50 \mu \mathrm{mol} \mathrm{L}^{-1}$ ) was added to the water of the incubation tank, and cores were preincubated in the dark at the in situ temperature for 2 to $5 \mathrm{~h}$. Three replicate cores were sacrificed by slurrying the entire sediment volume at approximately $0,2,5$ and $8 \mathrm{~h}$ following preincubation. Sediment was allowed to settle for $2 \mathrm{~min}$ before samples for gas $(12 \mathrm{~mL}$ Exetainers, Labco, UK, killed with $250 \mu \mathrm{L}$ zinc chloride solution, $50 \% \mathrm{w} / \mathrm{v}$ ) and nutrients $(10 \mathrm{~mL}$, killed with $250 \mu \mathrm{L}$ zinc chloride solution, frozen) were taken.

Sediment slurries were carried out in parallel to wholecore incubations. Briefly, a glass bead $(0.5 \mathrm{~cm} \varnothing)$ was added to each $12 \mathrm{~mL}$ Exetainer, which was then filled with filtered $(0.2 \mu \mathrm{m})$ helium-purged bottom water. Homogenized surface sediment ( $2 \mathrm{~mL}, 0-2 \mathrm{~cm}$ depth horizon) was added to each Exetainer, and vials were sealed. Exetainers were incubated on a shaker table in the dark at the in situ temperature for 8 to $12 \mathrm{~h}$ ensuring consumption of background $\mathrm{NO}_{3}^{-}$and $\mathrm{O}_{2}$ before addition of ${ }^{15} \mathrm{~N}$-substrates. Exetainers were divided into two treatments, amended with sodium ${ }^{15} \mathrm{~N}$-nitrate or with sodium ${ }^{14} \mathrm{~N}$-nitrite and ${ }^{15} \mathrm{~N}$-ammonium chloride (each $100 \mu \mathrm{mol} \mathrm{L}^{-1}$ final concentration). Slurries were sacrificed at approximately 0,5 and $10 \mathrm{~h}$ after substrate addition by injection of $250 \mu \mathrm{L}$ of zinc chloride solution through the septum of Exetainers. 
Table 3. Diffusive fluxes of pore water $\mathrm{H}_{2} \mathrm{~S}$.

\begin{tabular}{lrrrr}
\hline & Strömmen & Baggensfjärden & Erstaviken & Ingaröfjarden \\
\hline Sediment top $(\mathrm{cm})$ & 0.75 & 0.75 & 1.75 & 8.25 \\
Sediment bottom $(\mathrm{cm})$ & 2.25 & 7.25 & 8.25 & 15 \\
$\mathrm{H}_{2} \mathrm{~S}$ top $\left(\mu \mathrm{mol} \mathrm{L} \mathrm{L}^{-1}\right)$ & 2 & 3 & 7 & 36 \\
$\mathrm{H}_{2} \mathrm{~S}$ bottom $\left(\mu \mathrm{mol} \mathrm{L}^{-1}\right)$ & 385 & 899 & 1111 & 1340 \\
Diffusive flux $\left(\mathrm{mmol} \mathrm{m}^{-2} \mathrm{~d}^{-1}\right)$ & 7.6 & 4.2 & 5.2 & 6.5 \\
\hline
\end{tabular}

\subsubsection{Analytical methods}

Analysis of ${ }^{15} \mathrm{~N}$ composition of $\mathrm{N}_{2}$ (and any nitrous oxide, $\mathrm{N}_{2} \mathrm{O}$ ) was determined by gas chromatography isotope ratio mass spectrometry (GC-IRMS). A helium headspace was introduced to filled Exetainers, and gas samples were manually injected as described in Dalsgaard et al. (2013). Any ${ }^{15} \mathrm{~N}$ $\mathrm{N}_{2} \mathrm{O}$ was reduced in a reduction oven and measured as ${ }^{15} \mathrm{~N}$ $\mathrm{N}_{2}$. Determination of ${ }^{15} \mathrm{~N}_{\text {in }} \mathrm{NH}_{4}^{+}$was carried out by conversion of $\mathrm{NH}_{4}^{+}$to $\mathrm{N}_{2}$ with alkaline hypobromite iodine solution (Risgaard-Petersen et al., 1995; Füssel et al., 2012). Ammonium was extracted from sediment in slurry and whole-core samples by shaking for $1 \mathrm{~h}$ with $2 \mathrm{M} \mathrm{KCl}(1: 1$ sample $\mathrm{KCl})$ before any $\mathrm{NH}_{4}^{+}$analysis. The isotopic composition of the produced $\mathrm{N}_{2}$ was determined using a GC-IRMS as above. Recovery efficiency of ${ }^{15} \mathrm{NH}_{4}^{+}$following the hypobromite conversion was $>95 \%$.

Concentrations of $\mathrm{NO}_{x}\left(\mathrm{NO}_{3}^{-}+\mathrm{NO}_{2}^{-}\right)$in incubations were determined colorimetrically as described for pore water. For determination of total $\mathrm{NH}_{4}^{+}$, samples were extracted with $\mathrm{KCl}$ as above and $\mathrm{NH}_{4}^{+}$concentrations were analyzed colorimetrically using the salicylate-hypochlorite method (Bower and Holm-Hansen, 1980).

\subsubsection{Data calculations}

Anammox and DNRA were detectable in slurry incubations, although both processes only played a minor role in $\mathrm{NO}_{3}^{-}$ reduction at most sites. However, they may have interfered to a minor degree with the IPT calculations. Thus areal rates of benthic $\mathrm{N}$ cycling processes were calculated according to Song et al. (2016) at all sites. The relative contribution of anammox to $\mathrm{N}_{2}$ production ( $\mathrm{ra}$ ) in slurries was calculated as in Song et al. (2013) using the average mole fraction of ${ }^{15} \mathrm{NH}_{4}^{+}$in the total $\mathrm{NH}_{4}^{+}$pool $\left(F_{A}\right)$ as this was demonstrated to increase linearly over time.

Fluxes of $\mathrm{NO}_{3}^{-}$and $\mathrm{NH}_{4}^{+}$were calculated using gradients ( $\sim 0-1 \mathrm{~cm}$ and $\sim 0-5 \mathrm{~cm}$, respectively) of sediment pore water depth profiles and Fick's first law of diffusion. Porosity values were taken from the average porosities of the integrated depth horizons and diffusion coefficients from Schulz (2006).

\subsection{Sediment accumulation rates}

Freeze-dried sediment samples for Strömmen were measured for ${ }^{210} \mathrm{~Pb}$ by direct gamma counting using a high-purity germanium detector (Ortec GEM-FX8530P4-RB) at Lund University. ${ }^{210} \mathrm{~Pb}$ was measured by its emission at $46.5 \mathrm{keV}$. Selfabsorption was measured directly, and the detector efficiency was determined by counting a National Institute of Standards and Technology sediment standard. Excess ${ }^{210} \mathrm{~Pb}$ was calculated as the difference between the total measured ${ }^{210} \mathrm{~Pb}$ and the estimate of the supported ${ }^{210} \mathrm{~Pb}$ activity as given by ${ }^{214} \mathrm{~Pb}$ $\left({ }^{210} \mathrm{~Pb}_{\text {exc }}={ }^{210} \mathrm{~Pb}_{\text {total }}-{ }^{214} \mathrm{~Pb}\right)$.

Sediment accumulation rates for the four study sites were estimated by fitting a reactive transport model (Soetaert and Herman, 2009) to the ${ }^{210} \mathrm{~Pb}$ depth profiles accounting for depth-dependent changes in porosity (Fig. S2).

\section{Results}

\subsection{Pore water profiles}

The $\mathrm{O}_{2}$ penetration depth is deepest $(18 \mathrm{~mm})$ at Ingaröfjärden, while at the other three sites the $\mathrm{O}_{2}$ penetration depth is relatively shallow $(<4 \mathrm{~mm}$; Table 2; Fig. S3). The diffusive uptake of $\mathrm{O}_{2}$ is high at Strömmen and Baggensfjärden $\left(\sim 14 \mathrm{mmol} \mathrm{m}^{-2} \mathrm{~d}^{-1}\right)$ and low at Ingaröfjärden $\left(3 \mathrm{mmol} \mathrm{m}^{-2} \mathrm{~d}^{-1}\right.$; Table 2$)$. All four sites are characterized by a shallow sulfate methane transition zone (SMTZ), with near-complete $\mathrm{SO}_{4}^{2-}$ removal between 7 and $15 \mathrm{~cm}$ (Fig. 4). Concentrations of $\mathrm{CH}_{4}$ increase with depth at all sites and are highest at Erstaviken (up to $8 \mathrm{mmol} \mathrm{L}^{-1}$ ) and lowest at Ingaröfjärden (max. $\sim 2 \mathrm{mmol} \mathrm{L}^{-1}$ ). At Strömmen, Baggensfjärden and Erstaviken, $\mathrm{H}_{2} \mathrm{~S}$ concentrations increase rapidly with depths below $2 \mathrm{~cm}$, while at Ingaröfjärden this is observed below $10 \mathrm{~cm}$. After a distinct maximum (of up to $1.3 \mathrm{mM}$ in Ingaröfjärden), $\mathrm{H}_{2} \mathrm{~S}$ concentrations decrease again with depth and even reach values close to zero at Strömmen and Erstaviken (at approximately 20 and $40 \mathrm{~cm}$, respectively). The flux of $\mathrm{H}_{2} \mathrm{~S}$ towards the sediment surface is high at all sites $\left(\sim 4\right.$ to $\left.8 \mathrm{mmol} \mathrm{m}^{-2} \mathrm{~d}^{-1}\right)$.

Dissolved $\mathrm{Fe}^{2+}$ concentrations show a maximum directly below the sediment-water interface at all sites, with the highest maximum values at Strömmen $\left(\sim 60 \mu \mathrm{mol} \mathrm{L}^{-1}\right)$, and a rapid decrease to values around zero in the upper 


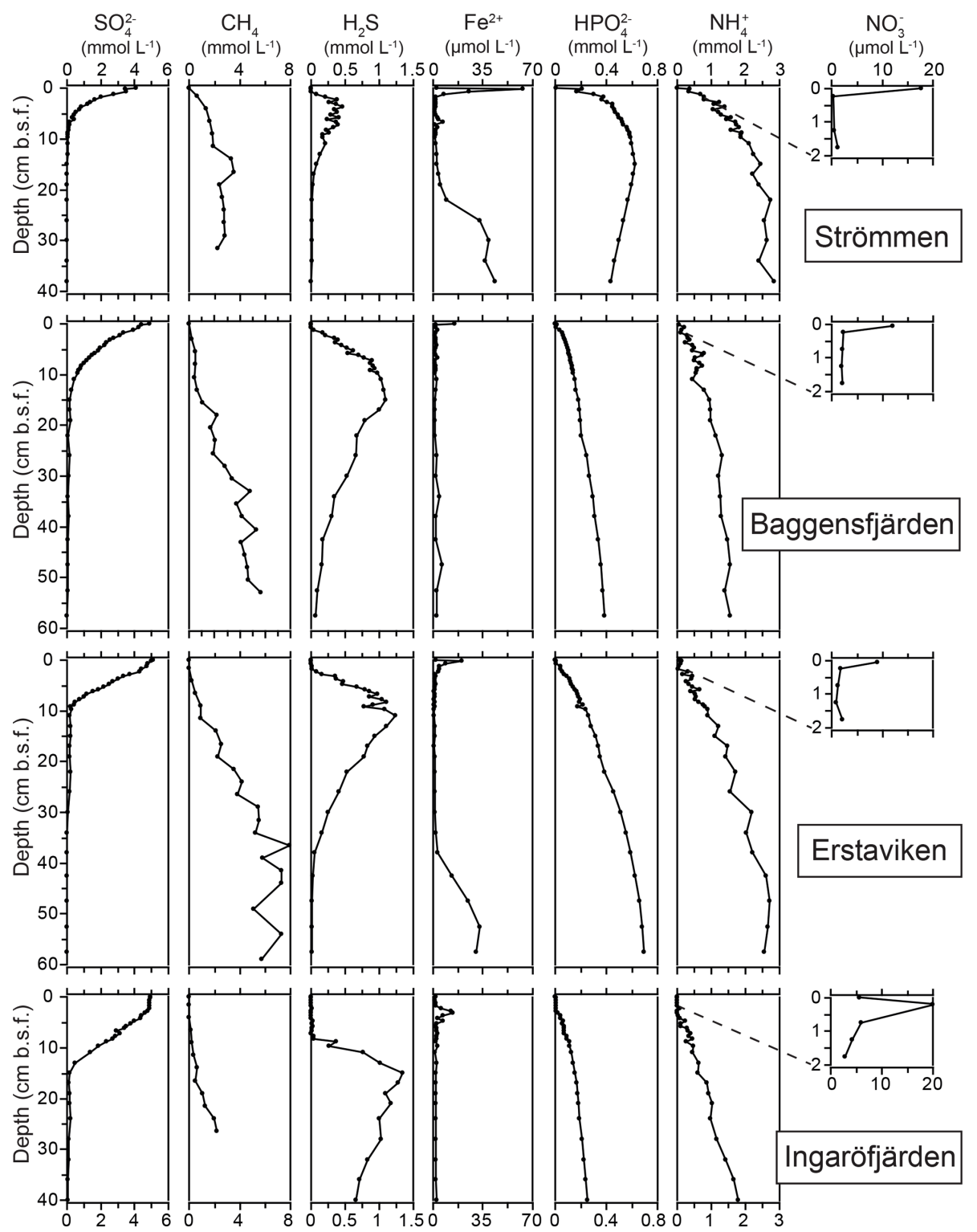

Figure 4. Pore water depth profiles of $\mathrm{SO}_{4}^{2-}, \mathrm{CH}_{4}, \mathrm{H}_{2} \mathrm{~S}, \mathrm{Fe}^{2+}, \mathrm{HPO}_{4}^{2-}, \mathrm{NH}_{4}^{+}$and $\mathrm{NO}_{3}^{-}$at the sites in the Stockholm archipelago: Strömmen, Baggensfjärden, Erstaviken and Ingaröfjärden.

centimeters of the sediment. At Strömmen and Erstaviken dissolved $\mathrm{Fe}^{2+}$ concentrations increase again when $\mathrm{H}_{2} \mathrm{~S}$ is depleted at depth. At all sites, concentrations of $\mathrm{HPO}_{4}^{2-}$ and $\mathrm{NH}_{4}^{+}$are low near the sediment-water interface and then increase with depth, first quickly then more gradually. Only at Strömmen does $\mathrm{HPO}_{4}^{2-}$ decrease below $\sim 15 \mathrm{~cm}$. Bottom water $\mathrm{NO}_{3}^{-}$concentrations decrease from the inner archipelago towards the outer archipelago, i.e., Strömmen $>$ Baggensfjärden $>$ Erstaviken $>$ Ingaröfjärden. For the three most inshore sites $\mathrm{NO}_{3}^{-}$concentrations in the bottom water are higher than $\mathrm{NO}_{3}^{-}$concentrations in the sediments. In contrast, at Ingaröfjärden $\mathrm{NO}_{3}^{-}$concentrations in the surface sediments are almost 4 times higher than $\mathrm{NO}_{3}^{-}$ concentrations in the bottom water.

\subsection{Solid-phase profiles}

Sediment $\mathrm{C}_{\text {org }}$ concentrations are relatively high at all four sites (Fig. 5), whereas $\mathrm{CaCO}_{3}$ concentrations are low (< $3 \mathrm{wt} \%$; Table 4). Surface sediments are enriched in $\mathrm{C}_{\text {org }}$ by 1-2 wt \% when compared to sediments at depth. Concentrations of $\mathrm{C}_{\text {org }}$ are highest at Strömmen and decrease from the inner archipelago towards the outer archipelago (Table 4; Fig. S4). Sediment $\mathrm{C} / \mathrm{N}$ ratios are somewhat lower in the top centimeters and become constant with depth. Overall $\mathrm{C} / \mathrm{N}$ values decrease towards the outer archipelago. At all four 


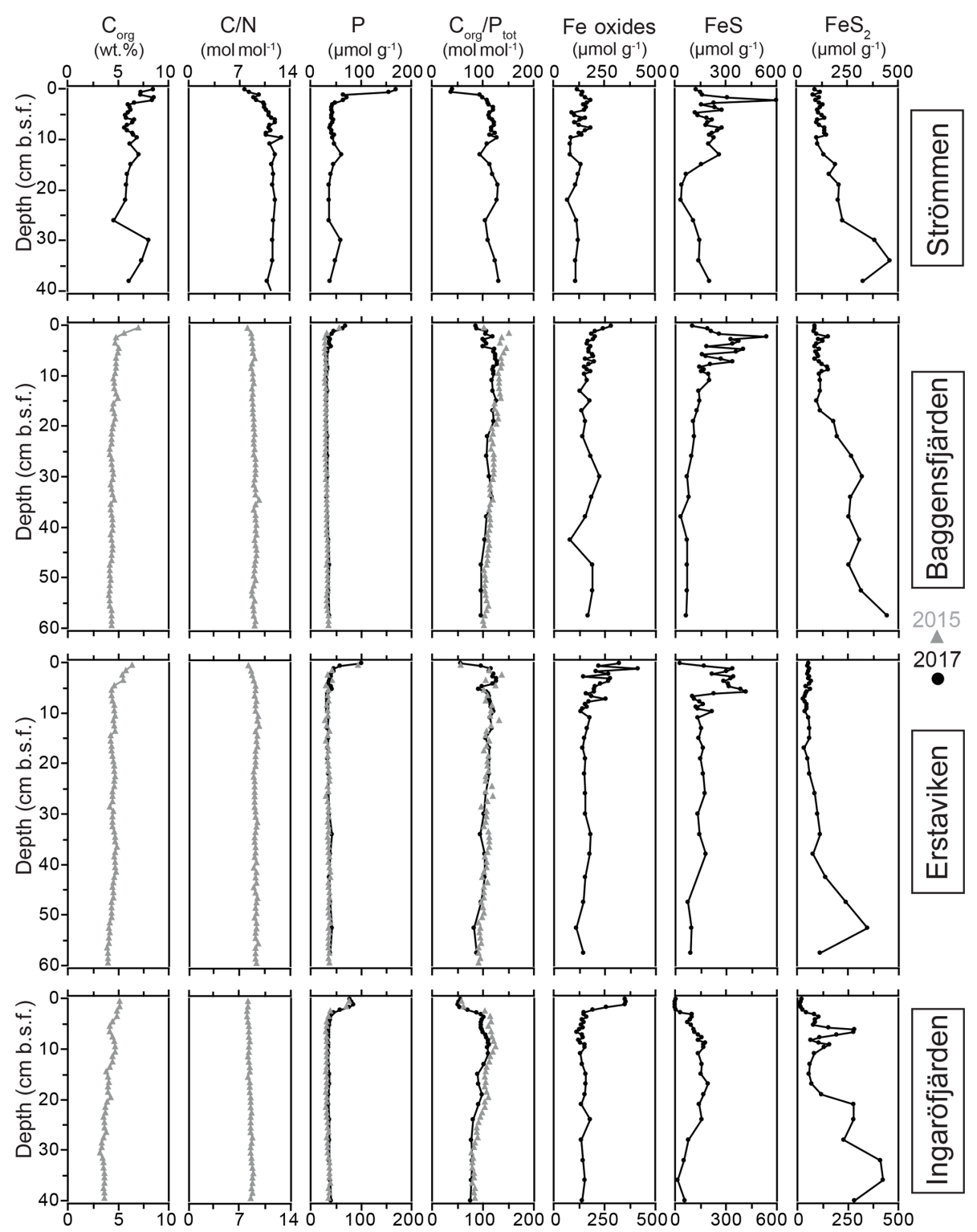

Figure 5. Solid-phase depth profiles of $\mathrm{C}_{\text {org }}, \mathrm{C} / \mathrm{N}, \mathrm{P}, \mathrm{C}_{\mathrm{org}} / \mathrm{P}_{\text {tot }}, \mathrm{Fe}$ oxides, FeS (AVS-derived) and FeS 2 (CRS-derived) for the study sites in the Stockholm archipelago: Strömmen, Baggensfjärden, Erstaviken and Ingaröfjärden. Grey triangles are data from van Helmond et al. (2020).

sites, surface sediments are enriched in P. The thickness of this enriched surface layer ranges from 2 to $4 \mathrm{~cm}$. At Strömmen, surface $\mathrm{P}$ concentrations are twice as high (ranging up to $165 \mu \mathrm{mol} \mathrm{g}^{-1}$ ) as those observed at the other sites. Below this enriched surface layer, $P$ concentrations are mostly rather constant at all sites (ranging from 30 to $40 \mu \mathrm{mol} \mathrm{g}^{-1}$ ). Similar to the high concentrations in the surface layer at Strömmen, sedimentary $\mathrm{P}$ concentrations are also high at depth (40 to $50 \mu \mathrm{mol} \mathrm{g}{ }^{-1}$ ), and two additional enrichments in $\mathrm{P}$ are observed at depth.

As a result of the relatively large enrichment in $\mathrm{P}$ in the surface sediments, $\mathrm{C}_{\text {org }} / \mathrm{P}_{\text {tot }}$ is low in the surface sediment. At depth $\mathrm{C}_{\text {org }} / \mathrm{P}_{\text {tot }}$ values are around the Redfield ratio (Ta- ble 4). With the exception of Strömmen, surface sediments are enriched in $\mathrm{Fe}$ oxides. This enrichment is most pronounced at Ingaröfjärden. At depth, Fe-oxide concentrations are relatively constant and similar for all four sites. Just below the surface, between $\sim 1$ to $10 \mathrm{~cm}$, a pronounced enrichment in $\mathrm{FeS}$ is observed. Only at Ingaröfjärden is such a pronounced enrichment in $\mathrm{FeS}$ not observed, and FeS are entirely absent above $2.5 \mathrm{~cm}$. Pyrite concentrations are relatively low in the surface sediments and gradually increase with depth. At Ingaröfjärden, a peak in $\mathrm{FeS}_{2}$ is observed between 5 and $10 \mathrm{~cm}$, superimposed on the gradual increase in $\mathrm{FeS}_{2}$. 


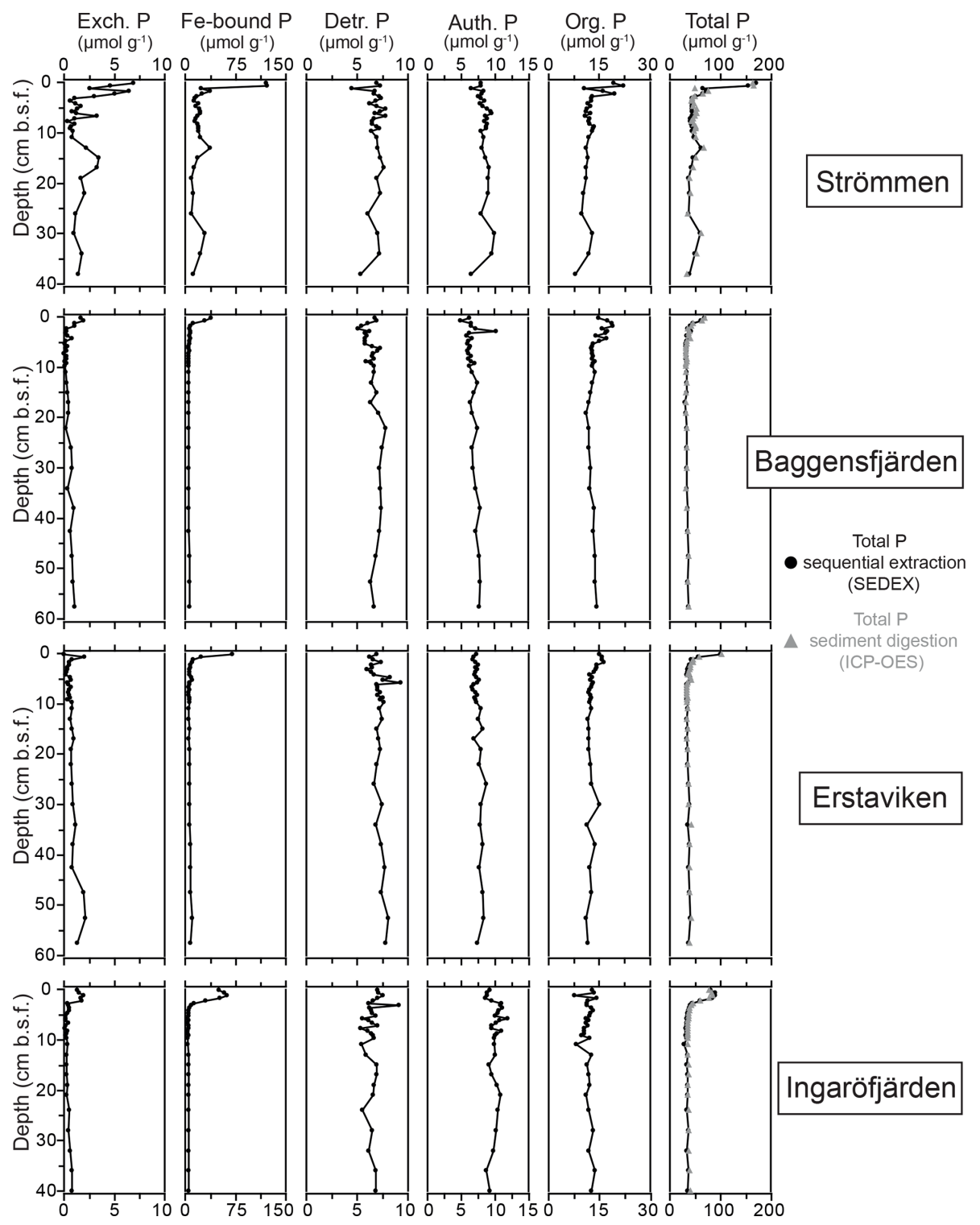

Figure 6. Depth profiles of the different fractions of solid-phase P for the study sites in the Stockholm archipelago: Strömmen, Baggensfjärden, Erstaviken and Ingaröfjärden. Total P is the sum of the different sequentially extracted P phases (SEDEX; black dots) and the P content derived from acid-digested sediment aliquots and subsequent ICP-OES analysis for the sediment samples taken in March 2017 (grey triangles).

At all sites, Fe-bound $\mathrm{P}$ dominates the $\mathrm{P}$ in the surface sediments (Fig. 6). At Strömmen, Fe-bound P remains an important fraction of solid-phase $\mathrm{P}$, also at depth, while for the other sites Fe-bound P only represents $\sim 10 \%-20 \%$ of total P. Exchangeable P shows trends similar to those observed for Fe-bound P, but concentrations are low. Detrital P, authigenic $\mathrm{P}$ and $\mathrm{P}$ in organic matter all show relatively constant concentrations with depth. Only the P in organic matter is slightly enriched in the surface sediments. Below the Fe-bound P-dominated surface sediments, $\mathrm{P}$ in organic matter is the largest fraction, representing between $\sim 30 \%$ and $40 \%$ of the total $\mathrm{P}$ and between $\sim 30 \%$ and $50 \%$ of reac- tive $\mathrm{P}$ (i.e., the sum of Fe-bound $\mathrm{P}$, exchangeable $\mathrm{P}$, $\mathrm{P}$ in organic matter and authigenic $\mathrm{Ca}-\mathrm{P}$ ). Authigenic $\mathrm{Ca}-\mathrm{P}$ represents $\sim 25 \%$ to $30 \%$ and detrital P $\sim 20 \%$ to $25 \%$ of total P.

\subsection{Benthic nitrogen cycling}

Bottom water $\mathrm{NO}_{3}^{-}$concentrations decrease from Strömmen $\left(17.8 \mu \mathrm{mol} \mathrm{L}^{-1}\right)$ towards Ingaröfjärden $\left(5.6 \mu \mathrm{mol} \mathrm{L}{ }^{-1}\right.$; Table 5). The flux of $\mathrm{NH}_{4}^{+}$out of the sediment also decreases seaward. The sediment acts as a weak source of $\mathrm{NO}_{3}^{-}$for the 
Table 4. Sedimentary concentrations of organic carbon $\left(\mathrm{C}_{\text {org }}\right)$, nitrogen $(\mathrm{N})$, phosphorus $(\mathrm{P})$ and calcium carbonate $(\mathrm{CaCO} 3)$ and $\mathrm{C} / \mathrm{N}$ and $\mathrm{C}_{\text {org }} / \mathrm{P}_{\text {tot }}$ ratios for the different study sites.

\begin{tabular}{|c|c|c|c|c|c|}
\hline & $\begin{array}{r}\text { Depth } \\
\text { interval }(\mathrm{cm})\end{array}$ & Strömmen & Baggensfjärden* & Erstaviken* & Ingaröfjärden* \\
\hline $\mathrm{C}_{\text {org }}$ avg. (wt \%) & $0-2$ & 7.9 & 6.3 & 6.0 & 5.1 \\
\hline $\mathrm{C}_{\text {org }}$ avg. (wt $\%$ ) & $10-40$ & 6.3 & 4.5 & 4.5 & 3.8 \\
\hline $\mathrm{CaCO}_{3}$ avg. (wt \%) & Entire core & 2.5 & 2.3 & 2.4 & 2.9 \\
\hline $\mathrm{N}$ avg. (wt \%) & $0-2$ & 0.99 & 0.83 & 0.78 & 0.69 \\
\hline $\mathrm{N}$ avg. (wt \%) & $10-40$ & 0.59 & 0.54 & 0.54 & 0.48 \\
\hline $\mathrm{P}$ avg. (wt \%) & $0-2$ & 0.36 & 0.17 & 0.19 & 0.25 \\
\hline $\mathrm{P}$ avg. (wt \%) & $10-40$ & 0.14 & 0.10 & 0.11 & 0.11 \\
\hline $\mathrm{C} / \mathrm{N}$ avg. $\left(\mathrm{mol}^{-1} \mathrm{~mol}^{-1}\right)$ & $0-2$ & 9.4 & 8.9 & 9.0 & 8.7 \\
\hline $\mathrm{C} / \mathrm{N}$ avg. $\left(\mathrm{mol}^{-1} \mathrm{~mol}^{-1}\right)$ & $10-40$ & 12.4 & 9.6 & 9.8 & 9.1 \\
\hline $\mathrm{C}_{\text {org }} / \mathrm{P}_{\text {tot }}$ avg. $\left(\mathrm{mol}^{-1} \mathrm{~mol}^{-1}\right)$ & $0-2$ & 69 & 96 & 95 & 53 \\
\hline $\mathrm{C}_{\text {org }} / \mathrm{P}_{\text {tot }}$ avg. $\left(\mathrm{mol}^{-1} \mathrm{~mol}^{-1}\right)$ & $10-40$ & 116 & 116 & 108 & 88 \\
\hline
\end{tabular}

* Organic carbon and nitrogen concentrations for Baggensfjärden, Erstaviken and Ingaröfjärden are derived from van Helmond et al. (2020).

Table 5. Areal rates of benthic $\mathrm{NO}_{3}^{-}$-reducing processes, including standard error (SE). Nitrification-denitrification indicates the proportion of denitrification supported by $\mathrm{NO}_{3}^{-}$from nitrification (as opposed to water column $\mathrm{NO}_{3}^{-}$). Bottom water $\mathrm{NO}_{3}^{-}$concentrations and $\mathrm{NH}_{4}^{+}$ and $\mathrm{NO}_{3}^{-}$fluxes from the surface sediments into the water column (calculated from pore water profiles), including standard error (SE), are shown.

\begin{tabular}{|c|c|c|c|c|}
\hline & Strömmen & Baggensfjärden & Erstaviken & Ingaröfjärden \\
\hline $\begin{array}{l}\text { Denitrification } \\
\left(\mu \mathrm{mol} \mathrm{N} \mathrm{m}^{-2} \mathrm{~d}^{-1}\right)(\mathrm{SE})\end{array}$ & $\begin{array}{l}1723 \\
(774)\end{array}$ & $\begin{array}{r}685 \\
(58)\end{array}$ & $\begin{array}{l}564 \\
(86)\end{array}$ & $\begin{array}{r}90 \\
(38)\end{array}$ \\
\hline $\begin{array}{l}\text { DNRA } \\
\left(\mu \mathrm{mol} \mathrm{m}^{-2} \mathrm{~d}^{-1}\right)(\mathrm{SE})\end{array}$ & $\begin{array}{l}11.1 \\
(8.1)\end{array}$ & $\begin{array}{r}6.1 \\
(1.7)\end{array}$ & $\begin{array}{r}3.6 \\
(3.3)\end{array}$ & $\begin{array}{r}2.8 \\
(0.4)\end{array}$ \\
\hline $\begin{array}{l}\text { Nitrification-denitrification } \\
\left(\mu \mathrm{mol} \mathrm{N} \mathrm{m}^{-2} \mathrm{~d}^{-1}\right)(\mathrm{SE})\end{array}$ & $\begin{array}{l}1027 \\
(461)\end{array}$ & $\begin{array}{l}500 \\
(42)\end{array}$ & $\begin{array}{l}500 \\
(76)\end{array}$ & $\begin{array}{r}76 \\
(32)\end{array}$ \\
\hline Nitrification-denitrification (\%) & 59.6 & 73 & 88.6 & 84.4 \\
\hline $\begin{array}{l}\text { Anammox } \\
\left(\mu \mathrm{mol} \mathrm{N} \mathrm{m}{ }^{-2} \mathrm{~d}^{-1}\right)(\mathrm{SE})\end{array}$ & $\begin{array}{l}0.27 \\
(0.1)\end{array}$ & $\begin{array}{l}0.76 \\
(0.1)\end{array}$ & $\begin{array}{l}3.11 \\
(0.5)\end{array}$ & $\begin{array}{l}44.12 \\
(18.4)\end{array}$ \\
\hline $\mathrm{N}_{2}$ anammox $(\%)$ & 0.02 & 0.11 & 0.55 & 32.93 \\
\hline Bottom water $\mathrm{NO}_{3}^{-}\left(\mu \mathrm{mol} \mathrm{L}{ }^{-1}\right)$ & 17.8 & 12.1 & 9.0 & 5.6 \\
\hline $\begin{array}{l}\mathrm{NH}_{4}^{+} \text {flux } \\
\left(\mu \mathrm{mol} \mathrm{N} \mathrm{m}^{-2} \mathrm{~d}^{-1}\right)(\mathrm{SE})\end{array}$ & $\begin{array}{r}1399 \\
(122.4)\end{array}$ & $\begin{array}{r}629 \\
(88.8)\end{array}$ & $\begin{array}{r}600 \\
(76.8)\end{array}$ & $\begin{array}{r}0 \\
(0)\end{array}$ \\
\hline $\begin{array}{l}\mathrm{NO}_{3}^{-} \text {flux } \\
\left(\mu \mathrm{mol} \mathrm{N} \mathrm{m} \mathrm{m}^{-2} \mathrm{~d}^{-1}\right)(\mathrm{SE})\end{array}$ & $\begin{array}{r}4.1 \\
(0.05)\end{array}$ & $\begin{array}{r}-1.44 \\
(1.0)\end{array}$ & $\begin{array}{l}-7.68 \\
(0.24)\end{array}$ & $\begin{array}{l}-85.7 \\
(35.0)\end{array}$ \\
\hline
\end{tabular}

overlying water at Strömmen, while it is a $\mathrm{NO}_{3}^{-}$sink at the other three sites (Table 5).

Denitrification is the major $\mathrm{NO}_{3}^{-}$-reducing process at all sites (Fig. 7; Table 5). Denitrification rates (Fig. 7) are highest at Strömmen $\left(\sim 1700 \mu \mathrm{mol} \mathrm{m}^{-2} \mathrm{~d}^{-1}\right)$ and decrease towards the outer archipelago with the lowest rates at Ingaröfjärden $\left(\sim 100 \mu \mathrm{mol} \mathrm{m}{ }^{-2} \mathrm{~d}^{-1}\right)$. Nitrous oxide is not an important end product of denitrification in whole-core incubations. Nitrification is the dominant source of $\mathrm{NO}_{3}^{-}$for den- itrification in the sediments at all sites, accounting for $60 \%-$ $89 \%$ of all $\mathrm{NO}_{3}^{-}$supply for denitrification in the sediments (Table 5; Fig. 8). The importance of nitrification as a $\mathrm{NO}_{3}^{-}$ source relative to water column $\mathrm{NO}_{3}^{-}$increased towards the outer archipelago. DNRA was measurable but is not a significant $\mathrm{NO}_{3}^{-}$-reducing pathway at any of the sites investigated, accounting for less than $1.5 \%$ of total $\mathrm{NO}_{3}^{-}$reduced. Anammox plays only a minor role in overall $\mathrm{N}$ removal $\left(<1 \% \mathrm{~N}_{2}\right.$ produced) at the three inner archipelago sites but accounts for 


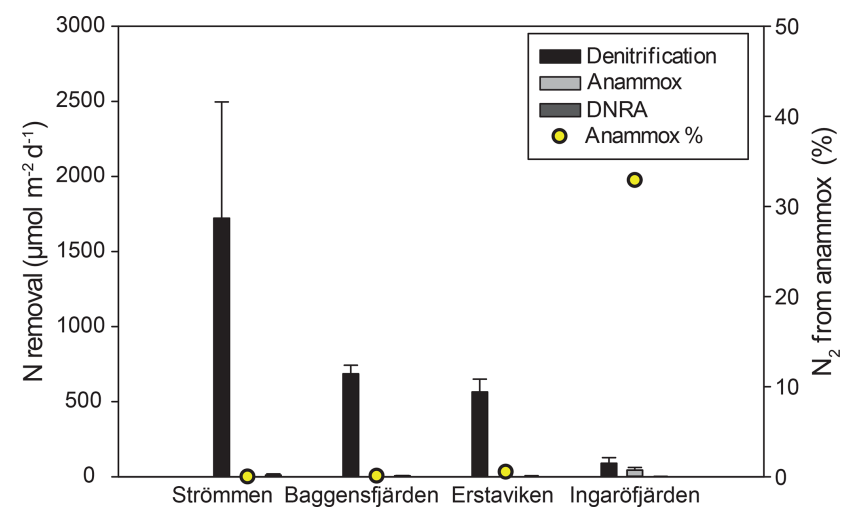

Figure 7. Bar diagram showing the areal rates of benthic $\mathrm{NO}_{3}^{-}$reducing processes, including error bars. Relative contribution of anammox is indicated by the yellow dots.

$33 \%$ of $\mathrm{N}_{2}$ production at Ingaröfjärden $\left(44.1 \mu \mathrm{mol} \mathrm{m} \mathrm{m}^{-2} \mathrm{~d}^{-1}\right)$, where overall $\mathrm{N}_{2}$ production is lowest and heterotrophic denitrification most limited in organic $\mathrm{C}$ substrate. Rates of $\mathrm{N}$ removal by denitrification are positively correlated with bottom water $\mathrm{NO}_{3}^{-}$concentrations and with organic carbon content (Fig. 9).

\section{Discussion}

\subsection{Phosphorus dynamics in a eutrophic coastal system}

\subsubsection{Phosphorus recycling}

At the end of autumn and during the winter dissolved $\mathrm{O}_{2}$ concentrations in the Stockholm archipelago peak, largely due to mixing of the water column and subsequent ventilation (Figs. 3c, d, S1). After winter, $\mathrm{O}_{2}$ concentrations decrease during spring and summer, following enhanced $\mathrm{O}_{2}$ consumption by degrading organic matter after the spring bloom and reaching minimum values at the end of summer and in autumn. The loss of $\mathrm{O}_{2}$ from the bottom water is further enhanced by reduced ventilation of deeper waters following intensified water column stratification as a result of formation or strengthening of the thermocline (Gidhagen, 1987), which at many locations in the Stockholm archipelago leads to hypoxia (Karlsson et al., 2010; Conley et al., 2011). In addition to nutrient availability, spring bloom intensity and water depth, hydrological restriction may contribute to low$\mathrm{O}_{2}$ conditions. This is also reflected at our study sites, with Baggensfjärden being the most $\mathrm{O}_{2}$-depleted and restricted basin (i.e., landlocked with narrow and relatively shallow connections to adjacent basins) and Ingaröfjärden being the least restricted and, subsequently, the most consistently welloxygenated basin throughout the year (Table 1; Figs. 1, 2, S1).

High dissolved $\mathrm{O}_{2}$ concentrations allow for the formation and presence of $\mathrm{Fe}$ oxides (Fig. 5) in the surface sediments that bind P (e.g., Slomp et al., 1996; Fig. 6). Low dissolved $\mathrm{O}_{2}$ concentrations, however, lead to the dissolution of $\mathrm{Fe}$ oxides in the surface sediments. The $\mathrm{P}$ associated with these $\mathrm{Fe}$ oxides can then be released into the water column again. This mechanism leads to $\mathrm{P}$ recycling in basins with strong (seasonal) contrasts in bottom water redox conditions, such as Baggensfjärden, where the sediments are a sink for $\mathrm{P}$ in the winter and a source of $\mathrm{P}$ in the spring and the summer (Fig. 3c), as also described previously for other basins in the Stockholm archipelago (Walve et al., 2018). Nevertheless, in year-round well-oxygenated basins, such as Ingaröfjärden, this seasonal $\mathrm{P}$ recycling is (nearly) absent (Fig. 3a). In such basins, deeper $\mathrm{O}_{2}$ penetration, which might partly be related to the presence of macrofauna (Fig. S3), leads to a thicker Feoxide-bearing layer (Fig. 5) and a larger and stable Fe-bound $\mathrm{P}$ pool (Fig. 6) and hence a larger enrichment of $\mathrm{P}$ in the surface sediments (Fig. 10). Besides Fe oxides, a major part of the surface sediment $\mathrm{P}$ pool consists of $\mathrm{P}$ in organic matter (Fig. 6), which, based on the $\mathrm{C} / \mathrm{N}$ values close to the Redfield ratio (Fig. 5), is predominantly of marine origin. Part of the organic matter (and the $\mathrm{P}$ associated with it) is lost with depth (Fig. 6), because the most labile organic matter is degraded in the upper centimeters of the sediment, releasing the $\mathrm{P}$ associated with it into the pore water. For our study sites in the Stockholm archipelago we calculated that this surface sediment $P$ pool, i.e., the $P$ active in turnover as already suggested by Rydin et al. (2011), varies between $0.036 \mathrm{~mol} \mathrm{P} \mathrm{m}^{-2}$ at Baggensfjärden and $0.172 \mathrm{~mol} \mathrm{P} \mathrm{m}^{-2}$ at Ingaröfjärden (between $\sim 1$ and $5 \mathrm{~g} \mathrm{P} \mathrm{m}^{-2}$, respectively; Fig. 10; Table 6). This is comparable to values found for previously studied sites in the Stockholm archipelago ( 1 to $7 \mathrm{~g} \mathrm{P} \mathrm{m}^{-2}$; Rydin et al., 2011; Rydin and Kumblad, 2019). The surface sediment P pool could, however, have been much larger for Strömmen, Baggensfjärden and Erstaviken if all of the FeS in the surface sediments had seasonally transformed into $\mathrm{Fe}$ oxides. The lack of such a transformation is likely linked to the high upward flux of $\mathrm{H}_{2} \mathrm{~S}$ to the surface sediment (4.2 to $7.6 \mathrm{mmol} \mathrm{m}^{-2} \mathrm{~d}^{-1}$; Table 3). Besides the $\mathrm{H}_{2} \mathrm{~S}$ flux, there is a relatively large efflux of $\mathrm{NH}_{4}^{+}$from the sediments into the bottom water (up to $1.4 \mathrm{mmol} \mathrm{m}^{-2} \mathrm{~d}^{-1}$; Table 5). Both the $\mathrm{H}_{2} \mathrm{~S}$ and the $\mathrm{NH}_{4}^{+}$flux originate from decomposing organicrich sediments at depth (Fig. 4). Upon aerobic oxidation, 2 mol of $\mathrm{O}_{2}$ is consumed per mole of $\mathrm{H}_{2} \mathrm{~S}$ or $\mathrm{NH}_{4}^{+}$(e.g., Reed et al., 2011). Thus, the $\mathrm{O}_{2}$ demand resulting from these $\mathrm{H}_{2} \mathrm{~S}$ and $\mathrm{NH}_{4}^{+}$fluxes is very high when compared to the diffusive flux of $\mathrm{O}_{2}$ into the sediment $\left(3.1-13.8 \mathrm{mmol} \mathrm{m}^{-2} \mathrm{~d}^{-1}\right.$; Table 2). As a consequence of the presence of $\mathrm{H}_{2} \mathrm{~S}$ in the surface sediments and its high upward flux, in combination with reduced water column mixing and/or seasonally low- $\mathrm{O}_{2}$ bottom water conditions, FeS are formed and/or preserved (Fig. 5) and formation of a large(r) pool of Fe oxides and a Fe-bound P pool is hindered at Strömmen, Baggensfjärden and Erstaviken. At Ingaröfjärden, the well-mixed water column and year-round well-oxygenated bottom water allow for a deeper $\mathrm{O}_{2}$ penetration (Fig. S3), preventing the presence of 

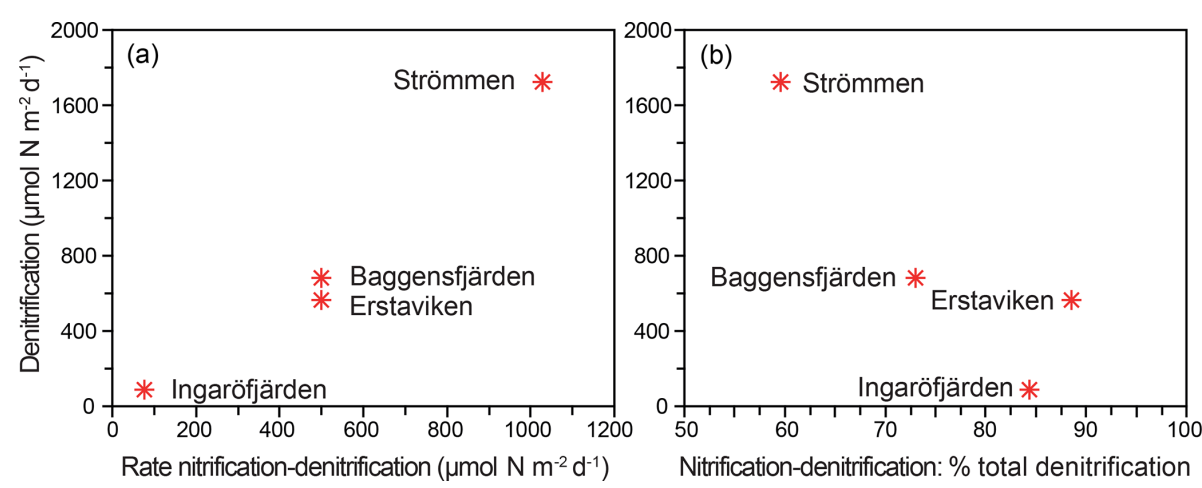

Figure 8. Relationship between total denitrification rates and denitrification driven by $\mathrm{NO}_{3}^{-}$from nitrification (nitrification-denitrification) as process rates (a) and as a percentage of total denitrification (b).

Table 6. Burial rates of total and reactive $\mathrm{P}$.

\begin{tabular}{|c|c|c|c|c|c|}
\hline & Unit & Strömmen & $\begin{array}{l}\text { Baggens- } \\
\text { fjärden }\end{array}$ & Erstaviken & $\begin{array}{l}\text { Ingarö- } \\
\text { fjärden }\end{array}$ \\
\hline \multirow[t]{2}{*}{ Total P burial rates } & $\mathrm{mol} \mathrm{m}^{-2} \mathrm{yr}^{-1}$ & 0.28 & 0.03 & 0.09 & 0.05 \\
\hline & $\mathrm{g} \mathrm{m}^{-2} \mathrm{yr}^{-1}$ & 8.74 & 0.87 & 2.89 & 1.53 \\
\hline \multirow[t]{2}{*}{ Reactive $\mathrm{P}^{\mathrm{a}}$ burial rates } & $\mathrm{mol} \mathrm{m}^{-2} \mathrm{yr}^{-1}$ & 0.24 & 0.02 & 0.07 & 0.03 \\
\hline & $\mathrm{g} \mathrm{m}^{-2} \mathrm{yr}^{-1}$ & 7.47 & 0.70 & 2.22 & 1.03 \\
\hline Thickness of enriched top layer ${ }^{b}$ & $\mathrm{~mm}$ & 30 & 20 & 20 & 40 \\
\hline \multirow{2}{*}{ Total P burial in enriched top layer } & $\mathrm{mol} \mathrm{m}^{-2}$ & 0.29 & 0.08 & 0.10 & 0.38 \\
\hline & $\mathrm{g} \mathrm{m}^{-2}$ & 9.12 & 2.50 & 3.19 & 11.85 \\
\hline \multirow[t]{2}{*}{ Total P burial in enriched top layer - background } & $\mathrm{mol} \mathrm{m}^{-2}$ & 0.160 & 0.036 & 0.047 & 0.172 \\
\hline & $\mathrm{g} \mathrm{m}^{-2}$ & 4.96 & 1.11 & 1.47 & 5.33 \\
\hline \multirow[t]{2}{*}{ Reactive P burial in enriched top layer } & $\mathrm{mol} \mathrm{m}^{-2}$ & 0.24 & 0.067 & 0.081 & 0.32 \\
\hline & $\mathrm{g} \mathrm{m}^{-2}$ & 7.49 & 2.07 & 2.51 & 10.05 \\
\hline \multirow[t]{2}{*}{ React. $\mathrm{P}$ burial in enriched top layer - background } & $\mathrm{mol} \mathrm{m}^{-2}$ & 0.127 & 0.031 & 0.039 & 0.200 \\
\hline & $\mathrm{g} \mathrm{m}^{-2}$ & 3.94 & 0.94 & 1.20 & 6.21 \\
\hline \multirow[t]{2}{*}{ Sediment accumulation rate ${ }^{c}$} & $\mathrm{~mm} \mathrm{yr}^{-1}$ & 35 & 5 & 15 & 5 \\
\hline & $\mathrm{g} \mathrm{DW} \mathrm{m}^{-2} \mathrm{yr}^{-1}$ & 6300 & 865 & 2588 & 1353 \\
\hline
\end{tabular}

$\mathrm{H}_{2} \mathrm{~S}$ in the surface sediment despite its high upward flux (Table 3) and leading to a thicker Fe-oxide-bearing layer (Fig. 5) and a larger Fe-bound P pool (Fig. 6).

\subsubsection{Phosphorus burial}

Absolute $\mathrm{P}$ concentrations in the sediments in the Stockholm archipelago (Figs. 6 and 10 in this study and in Rydin et al., 2011) are high ( $~ 30$ to $\left.50 \mu \mathrm{mol} \mathrm{g}^{-1}\right)$ in comparison with most other studied sites in the coastal zone of the Baltic Sea (generally $<30 \mu \mathrm{mol} \mathrm{g}{ }^{-1}$; Jensen et al., 1995; Carman et al., 1996; Lenstra et al., 2018). The relatively low $\mathrm{C}_{\text {org }} / \mathrm{P}_{\text {tot }}$ values in the top $\sim 2 \mathrm{~cm}$, which are around the Redfield ratio
(Fig. 5), show that the seasonal $\mathrm{O}_{2}$ depletion of bottom waters in our study area is not severe or long-lasting enough to cause substantial preferential regeneration of $\mathrm{P}$ relative to C (Algeo and Ingall, 2007; Sulu-Gambari et al., 2018). The combination of high absolute $\mathrm{P}$ concentrations and relatively high sedimentation rates leads to relatively high rates of $\mathrm{P}$ burial (Table 6; Fig. S5). Further research of P burial rates at additional locations in the Stockholm archipelago, including the impact of anthropogenic activities on sedimentation rates (e.g., near-shore construction and dredging) and of redeposition of sediments that have already undergone one or multiple diagenetic cycles (after resuspension due to, for example, 

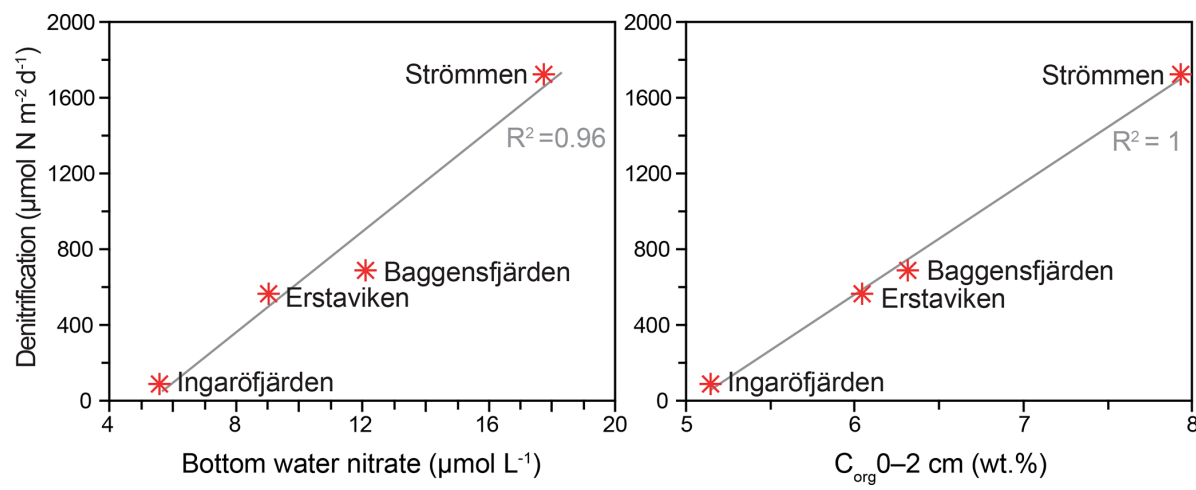

Figure 9. Relationship between denitrification and bottom water $\mathrm{NO}_{3}^{-}$concentrations on the one hand and upper sediment $\mathrm{C}_{\text {org }}$ content on the other for the study sites in the Stockholm archipelago.

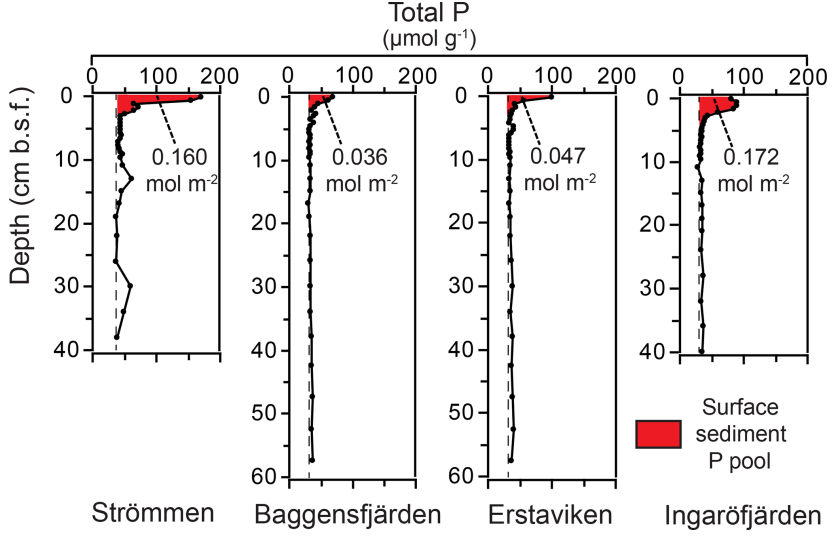

Figure 10. Surface sedimentary $\mathrm{P}$ pools for the study sites in the Stockholm archipelago. The red color indicates the enriched surface sediment layer or "top layer" (Table 6). Dashed lines indicate "background" sedimentary P.

land uplift; Jonsson et al., 1990; Bryhn and Håkanson, 2011) is required before these results can be extrapolated to the scale of the entire system. Furthermore, it remains unclear what parts of the Stockholm archipelago represent areas of net sediment accumulation (Karlsson et al., 2019; Asmala et al., 2019) and how much (and in what form) $P$ is buried in euxinic parts of the Stockholm archipelago. Hence, our results cannot be directly used to resolve the apparent discrepancy between the model results of Almroth-Rosell et al. (2016) and Walve et al. (2018).

The constant concentrations of most $\mathrm{P}$ forms in the sediment below the clearly enriched surface sediments suggest there is generally little to no sink switching of sediment $\mathrm{P}$ forms (i.e., the transformation of relatively labile $\mathrm{P}$ reservoirs such as Fe-oxide-bound $\mathrm{P}$ and organic $\mathrm{P}$ to authigenic $\mathrm{P}$ minerals such as vivianite) in the Stockholm archipelago. The curved shape of the pore water $\mathrm{HPO}_{4}^{2-}$ profiles indicates, however, that there is still some release of $\mathrm{P}$ into the pore water at depth, and we attribute this to slow degradation of organic matter. Both the detrital and authigenic (Ca-P) fractions are likely buried in the form in which they reached the sediment-water interface. The general dominance of $\mathrm{P}$ in organic matter and apatite (authigenic and detrital P; Fig. 6) at depth (representing permanent $P$ burial, since the release of $\mathrm{P}$ from organic $\mathrm{P}$ is only minor) agrees with previous findings for organic-rich sediments in the Baltic Sea (e.g., Jensen et al., 1995; Carman et al., 1996; Mort et al., 2010; Rydin et al., 2011). By contrast, in the Bothnian Sea, Fe-bound P is a much more important $\mathrm{P}$ pool at depth (e.g., Egger et al., 2015; Lenstra et al., 2018). Evidence for potential sink switching is only found at Strömmen, which is characterized by a larger Fe-bound P pool at depth (Fig. 6). This larger Febound $\mathrm{P}$ pool at depth contributes to the high $\mathrm{P}$ burial rate at Strömmen (Table 6; Fig. S5). Coastal sediments with a shallow SMTZ, relatively high inputs of Fe oxides and organic matter, and high sediment accumulation rates are prime locations for formation of vivianite-type minerals (e.g., Slomp et al., 2013; Egger et al., 2015). The presence of dissolved $\mathrm{Fe}^{2+}$ and decreasing dissolved $\mathrm{HPO}_{4}^{2-}$ concentrations at depth at Strömmen (Fig. 4) in combination with elevated Fe-bound P in the lower part of the record (Fig. 6) may hence result from the formation of a vivianite-type mineral.

\subsection{Nitrogen cycling in the Stockholm archipelago}

\subsubsection{Spatial differences in benthic $\mathbf{N}$ dynamics}

Denitrification is by far the dominant pathway of $\mathrm{NO}_{3}^{-}$reduction at our study sites, accounting for $\sim 80 \%$ to $99 \%$ of total dissimilatory $\mathrm{NO}_{3}^{-}$reduction (DNRA + anammox + $(2 \times$ denitrification) $)$ at the time of sampling (Table 4$)$.

The dominant role of denitrification in removing $\mathrm{N}$ and the gradient from inner to outer archipelago agrees well with regional models based on long-term monitoring data, which show the highest $\mathrm{N}$ removal capacity in the inner archipelago region (Almroth-Rosell et al., 2016; Edman et al., 2018). In the model of Almroth-Rosell et al. (2016), the inner archipelago, where Strömmen is located, annually removes 
approximately 3-5 times more $\mathrm{N}\left(\sim 8-12 \mathrm{tN} \mathrm{km}^{-2} \mathrm{yr}^{-1}\right)$ than the intermediate and outer archipelago sites $(\sim 1-3 \mathrm{tN}$ $\mathrm{km}^{-2} \mathrm{yr}^{-1}$ ). Denitrification rates of both Baggensfjärden and Erstaviken are within this range $(\sim 2.5$ and $\sim 3$ times lower than at Strömmen, respectively). However, despite Ingaröfjärden being located in a basin adjacent to Erstaviken (Fig. 1) and modeled as having an almost identical areaspecific N retention capacity (Almroth-Rosell et al., 2016), denitrification rates were almost 20 times lower than those at Strömmen and $\sim 8$ to 6 times lower than at Baggensfjärden and Erstaviken, respectively. As such, $\mathrm{N}$ removal rates between adjacent basins may be more variable than assumed by models. The differences in rates are likely related to lower organic matter inputs and subsequent lower sediment respiration rates as indicated by deeper $\mathrm{O}_{2}$ penetration at Ingaröfjärden (Table 2; Fig. S3). Suspended particulate organic matter may also be removed more quickly from Ingaröfjärden due to its more direct connection to the open Baltic Sea (Fig. 1), permitting more rapid water exchange and transport of particulate organic matter out of the basin than at Baggensfjärden and Erstaviken (Engqvist and Andrejev, 2003).

\subsubsection{Controls on benthic $\mathrm{NO}_{3}^{-}$reduction}

Given the minor contributions of anammox and DNRA in these sediments at the time of sampling, we focus predominantly on the control of heterotrophic denitrification in Stockholm archipelago sediments. Heterotrophic denitrification in sediments is limited by both the availability of $\mathrm{NO}_{3}^{-}$ and $\mathrm{C}_{\mathrm{org}}$.

In sediments, $\mathrm{NO}_{3}^{-}$is supplied from overlying water and/or from nitrification in the surface layers (coupled nitrification-denitrification; Seitzinger, 1988; Seitzinger et al., 2006). The relative importance of the two $\mathrm{NO}_{3}^{-}$sources to denitrification in coastal systems can be highly variable between locations and seasons (e.g., Seitzinger et al., 2006; Jäntti et al., 2011; Bonaglia et al., 2014). We observed a distinct positive correlation between rates of denitrification and bottom water $\mathrm{NO}_{3}^{-}$concentration (Fig. 9), indicating a high capacity of the sediments to reduce riverine $\mathrm{NO}_{3}^{-}$loads along the seaward gradient, as shown for other coastal systems of the Baltic Sea (Asmala et al., 2017). We additionally demonstrate that benthic nitrification provided the major proportion $(\sim 55 \%-90 \%)$ of $\mathrm{NO}_{3}^{-}$which was reduced in the sediments at all four sites (Table 5; Fig. 8), as has been demonstrated in previous studies and syntheses on coastal systems (e.g., see Seitzinger et al., 2006) and studies on the Baltic Sea (e.g., Silvennoinen et al., 2007; Bonaglia et al., 2014, 2017; Hellemann et al., 2017). One of the highest contributions of nitrification to $\mathrm{NO}_{3}^{-}$production for denitrification $(\sim 85 \%)$ was measured at Ingaröfjärden. At this site, the lowest overall denitrification rates and bottom water $\mathrm{NO}_{3}^{-}$ concentrations were measured, despite the deep $(18 \mathrm{~mm}) \mathrm{O}_{2}$ penetration providing a large sediment volume for nitrification to occur (Table 2). This high $\mathrm{O}_{2}$ penetration may in part be due to fewer $\mathrm{C}_{\text {org }}$ inputs and thus a lower $\mathrm{C}_{\text {org }}$ content (Table 2), discussed in Sect. 4.2.1 and further below.

Inputs of $\mathrm{C}_{\text {org }}$ provide both a $\mathrm{C}$ source for heterotrophic processes (e.g., denitrification) as well as a source of $\mathrm{NH}_{4}^{+}$ (from remineralization processes) for nitrification and subsequent $\mathrm{NO}_{3}^{-}$production. In coastal sediments $\mathrm{C}_{\text {org }}$ is not thought to limit denitrification. However, in complex basin systems such as the Stockholm archipelago, and in the Baltic Sea coastal zone in general, differences in ventilation and retention times between basins (implying differences in vertical and lateral exchange of water and $\mathrm{O}_{2}$ and, hence, variations in bottom water $\mathrm{O}_{2}$ ) may mean that $\mathrm{C}_{\text {org }}$ inputs are more variable than assumed (see Sect. 4.2.1). Available $\mathrm{C}_{\text {org }}$ in Ingaröfjärden (Table 2) may be less labile than it is at other sites due to such variations in hydrology and bottom water $\mathrm{O}_{2}$, with the deep $(18 \mathrm{~mm}) \mathrm{O}_{2}$ penetration indicating a lower organic matter reactivity and sediment respiration compared to the other sites. Lower labile $\mathrm{C}_{\text {org }}$ availability will limit heterotrophic denitrification and may explain why anammox, an autotrophic process, is more dominant at this site (Table 5; Fig. 7). The presence of the invasive polychaete Marenzelleria (Table 2) may also reduce $\mathrm{N}$ removal at Ingaröfjärden and enhance the efflux and transport of $\mathrm{NH}_{4}^{+}$from sediments (e.g., Hietanen et al., 2007; Bonaglia et al., 2013), although it should be noted that the impacts of infauna on $\mathrm{N}$ cycling are notoriously complex (Robertson et al., 2019).

\subsubsection{Seasonal cycles of $\mathrm{N}$ processes}

Sampling and experiments in this study were carried out in late winter (March), a period in the Baltic Sea when the water column is well mixed, with cold and well-oxygenated bottom waters and with persistently low organic inputs to sediments. However, conditions are of course not static throughout the annual cycle. Seasonal warming, stratification, phytoplankton blooms, and consumption and release of nutrients as seen in year-round monitoring data (Figs. 3d, S1) will have marked effects on sediment nutrient cycling. Yearround bottom water monitoring data collected at Bäggensfjärden show that $\mathrm{NO}_{3}^{-}$accumulates annually in bottom waters during the autumn and winter months before being consumed during spring and summer by phytoplankton blooms (Fig. 3d). Hypoxic bottom waters develop over summer following bloom collapse and subsequent enhanced deposition of fresh organic matter and enhanced benthic respiration during summer and early autumn. Bottom water total $\mathrm{N}$ concentrations increase during summer in connection with the hypoxic events (Fig. 3d) due to enhanced benthic remineralization and subsequent $\mathrm{NH}_{4}^{+}$efflux from sediments.

Increased organic inputs following the spring bloom are likely to lead to increases in denitrification as the season progresses, as is commonly observed in coastal sediments (e.g., Piña-Ochoa and Álvarez-Cobelas, 2006; Jäntti et al., 2011; Bonaglia et al., 2014). Thus, a scenario would be assumed for the Stockholm archipelago that is similar to those 
for other estuaries, leading to higher rates of denitrification during spring and early summer and a reduction in autumn and winter as organic inputs subside (e.g., Bonaglia et al., 2014). Depending on the bloom intensity and organic matter inputs during spring, increased benthic respiration may lead to more reduced conditions in surface sediments as bottom water $\mathrm{O}_{2}$ is depleted. The availability of $\mathrm{NO}_{3}^{-}$also declines under hypoxic-anoxic conditions due to $\mathrm{NO}_{3}^{-}$consumption in the water column, lower $\mathrm{O}_{2}$ penetration and thus a reduced volume of surface sediment where nitrification can occur and due to the reduced efficiency of nitrification under low- $\mathrm{O}_{2}$ conditions. The resulting high $\mathrm{C} / \mathrm{N}$ conditions may cause process dominance to shift from $\mathrm{N}$ removal by denitrification (or anammox) to retention by DNRA (e.g., An and Gardner, 2002; Burgin and Hamilton, 2007; Giblin et al., 2013; Algar and Vallino, 2014; Kraft et al., 2014), as has been repeatedly demonstrated in field, laboratory and model studies (An and Gardner, 2002; Algar and Vallino, 2014; Kraft et al., 2014; van den Berg et al., 2016; Kessler et al., 2018). Thus, under hypoxic conditions in summer and autumn, DNRA may become the dominant $\mathrm{NO}_{3}^{-}$-reducing process, altering the role of sediments from a $\mathrm{NO}_{3}^{-}$sink through $\mathrm{N}_{2}$ production to a source via increased $\mathrm{NH}_{4}^{+}$release by DNRA.

While we have not assessed the $\mathrm{NO}_{3}^{-}$-reducing process over different seasons at these four sites, we have demonstrated that the microbial metabolic potential for DNRA is present through the detection of DNRA activity in incubations at all four sites (Table 5). We suggest that it is highly likely that DNRA contributes to $\mathrm{NH}_{4}^{+}$efflux at sites during sporadic bottom water hypoxia. Thus, the capacity for $\mathrm{N}$ removal by denitrification may be reduced during bottom water hypoxia, while the likelihood of $\mathrm{N}$ recycling by DNRA increases as shown in previous Baltic Sea studies (e.g., Jäntti et al., 2011; Jäntti and Hietanen, 2012; Bonaglia et al., 2014).

\subsection{Implications for future water quality in the Stockholm archipelago}

Continued decreases in nutrient inputs to the Baltic Sea (Gustafsson et al., 2012; Andersen et al., 2017) and the Stockholm archipelago (Karlsson et al., 2010) are likely to reduce phytoplankton growth, leading to reduced organic matter input into the sediments and, eventually, to higher $\mathrm{O}_{2}$ concentrations in bottom waters.

Our results indicate that increases in bottom water $\mathrm{O}_{2}$ would likely impede the observed present-day P-recycling pattern at the seasonally hypoxic sites (Fig. 3c), allowing for thicker Fe-oxide-bearing layers and a larger Fe-bound $\mathrm{P}$ pool in the surface sediments (e.g., Slomp et al., 1996) and hence a larger (semipermanent) surface sedimentary $\mathrm{P}$ pool. This process will, however, be delayed due to the prior deposition of organic-rich sediments which results in a high upward flux of $\mathrm{H}_{2} \mathrm{~S}$ (Table 3), i.e., legacy of hypoxia hindering the formation of $\mathrm{Fe}$ oxides that can bind P. Because of this legacy effect, we expect that artificial reoxygenation of bottom waters (e.g., Stigebrandt et al., 2015), if applied in the Stockholm archipelago, is unlikely to be a long-term effective measure towards improving the water quality since it does not stimulate permanent $\mathrm{P}$ burial in these sediments and a large impact on the Fe-P pool is hindered by the high upward $\mathrm{H}_{2} \mathrm{~S}$ flux. Further nutrient reduction for the Stockholm archipelago is expected to eventually lead to a reversal from export of $\mathrm{P}$ to the open Baltic Sea to import of $\mathrm{P}$ from the open Baltic Sea (Savchuk, 2005; Almroth-Rosell et al., 2016). This shows that improvement of the water quality in the Stockholm archipelago is to a great extent coupled to nutrient management strategies for the entire Baltic Sea.

Our results indicate that, in the Stockholm archipelago, N likely goes through cycles of retention and removal throughout the year in relation to bottom water hypoxia. $\mathrm{N}$ is removed by denitrification during colder months when $\mathrm{NO}_{3}^{-}$ availability is high, while DNRA is likely to increase during hypoxic, $\mathrm{NO}_{3}^{-}$-depleted months. Reductions in the frequency of hypoxic bottom waters will thus reduce the amount of time that sediments potentially recycle bioavailable $\mathrm{N}$ via DNRA, and sediments may be more likely to act as a net sink for $\mathrm{N}$ through denitrification on an annual basis.

Continued recovery of the Stockholm archipelago is also likely to lead to (re)colonization by bioturbating macrofaunal populations that have been driven out by hypoxic bottom waters (Diaz and Rosenberg, 2008; Voss et al., 2011). This may enhance temporary $\mathrm{P}$ burial and denitrification by sediment reworking and oxygenation (e.g., Pelegri and Blackburn, 1995; Laverock et al., 2011; Norkko et al., 2012). While we still lack the predictive capabilities required to allow us to assess how fauna may influence sediment biogeochemistry (Griffiths et al., 2017; Robertson et al., 2019), reductions in nutrient inputs and phytoplankton bloom intensities and eventual recolonization by fauna at inner archipelago sites will likely sustain active $\mathrm{P}$ and $\mathrm{N}$ removal processes. Thus, these coastal sediments are likely to continue to contribute to removal of $\mathrm{P}$ and $\mathrm{N}$ as long as we continue to actively reduce nutrient inputs.

\section{Conclusions}

Seasonally hypoxic sites in the Stockholm archipelago are characterized by active sedimentary $\mathrm{P}$ recycling, because low bottom water $\mathrm{O}_{2}$ concentrations seasonally destabilize $\mathrm{Fe}$ oxides that bind $\mathrm{P}$ in the surface sediments. A high upward flux of $\mathrm{H}_{2} \mathrm{~S}$, due to prior deposition of organic-rich sediments in a low- $\mathrm{O}_{2}$ setting, leads to the formation and preservation of $\mathrm{FeS}_{x}$ instead of the burial of $\mathrm{Fe}$ oxides at these sites. At the site where bottom waters are well-oxygenated year round, the surface sedimentary P pool is mainly characterized by $\mathrm{P}$ bound to $\mathrm{Fe}$ oxides and organic matter, in a pool that is 5 times larger than that at the most hypoxic site $(\sim 0.172$ versus $\sim 0.036 \mathrm{~mol} \mathrm{P} \mathrm{m}^{-2}$ ). At depth, sedimentary $\mathrm{P}$ is dominated by $\mathrm{P}$ in organic matter and apatite. Only for the site 
in the inner archipelago (Strömmen) is there an indication of sink switching, i.e., authigenic formation of a vivianite-type $\mathrm{Fe}(\mathrm{II})-\mathrm{P}$ mineral, at depth. Burial rates of $\mathrm{P}$ at our sites in the Stockholm archipelago are high $\left(0.03-0.3 \mathrm{~mol} \mathrm{~m}^{-2} \mathrm{yr}^{-1}\right)$ because of the combined effect of high sediment accumulation rates and high sedimentary concentrations of $\mathrm{P}$. Benthic denitrification is the primary $\mathrm{NO}_{3}^{-}$-reducing pathway in the Stockholm archipelago, leading to remediation of $\mathrm{NO}_{3}^{-}$introduced from the water column and from benthic nitrification. Decreases in denitrification rates follow the gradient of bottom water $\mathrm{NO}_{3}^{-}$and sedimentary $\mathrm{C}_{\text {org }}$ content from the inner archipelago towards the open Baltic Sea from $\sim 1700$ to $\sim 100 \mu \mathrm{mol} \mathrm{N} \mathrm{m} \mathrm{d}^{-1}$. Combining our process measurements with available monitoring data, it is likely that $\mathrm{N}$ in the Stockholm archipelago undergoes seasonal cycles of removal through denitrification and anammox and recycling by DNRA. Further reductions in $\mathrm{P}$ and $\mathrm{N}$ inputs are expected to reduce the frequency of hypoxic events. Our results show that the permanent burial of $\mathrm{P}$ is largely independent of bottom water redox conditions. Increased bottom water oxygen is expected to allow benthic denitrification to be sustained. Hence, we expect that the sediments in the Stockholm archipelago will continue to remove part of the $\mathrm{P}$ and $\mathrm{N}$ loads upon reduction in such loads.

Code availability. Monitoring data can be extracted from the SHARK database at http://www.smhi.se/klimatdata/oceanografi/ havsmiljodata/marina-miljoovervakningsdata (SMHI, 2019). All other data, if not directly available from the tables and supplement, will be made available in the PANGAEA database. In the meantime data are available upon request to the authors.

Supplement. The supplement related to this article is available online at: https://doi.org/10.5194/bg-17-2745-2020-supplement.

Author contributions. NAGMvH, EKR, DJC and CPS designed the research. NAGMvH, EKR, MH, CH, WKL and CPS carried out the fieldwork. NAGMvH, EKR, MH, LJK and WKL performed the analyses. All authors interpreted the data. NAGMvH, EKR and CPS wrote the paper with comments provided by DJC, MH, CH, LJK and WKL.

Competing interests. The authors declare that they have no conflict of interest.

Special issue statement. This article is part of the special issue "Ocean deoxygenation: drivers and consequences - past, present and future (BG/CP/OS inter-journal SI)". It is not associated with a conference.
Acknowledgements. We thank the captain and crew of the $\mathrm{R} / \mathrm{V}$ Electra, Laurine Burdorf, and Katharina Theopold for their help during the research cruise in the Stockholm archipelago in March 2017. Arnold van Dijk, Coen Mulder, Thom Claessen, Floor Wille, Alexander Dorgelo and Joyce Maine (Utrecht University) and Rosine Cartier (Lund University) are thanked for analytical assistance. We thank Volker Brüchert (Stockholm University) for lending the whole-core incubation equipment, Morten Larsen and Bo Thamdrup (University of Southern Denmark) for allowing us to borrow the gas mixer and for the use of the GC-IRMS for ${ }^{15} \mathrm{~N}$ isotope analyses.

Financial support. This research has been supported by the Havsoch vattenmyndigheten (grant no. DNR 1960-2018); the European Research Council and FORMAS (BONUS COCOA project, grant no. 2112932-1); the Dutch Ministry of Education, Culture and Science (under the program of the Netherlands Earth System Science Centre); the Nederlandse Organisatie voor Wetenschappelijk Onderzoek (Vici grant, grant no. 865.13.005); and the European Research Council (Starting Grant, grant no. PHOXY (278364)), the last two grants being awarded to Caroline P. Slomp.

Review statement. This paper was edited by Hermann Bange and reviewed by Emil Rydin, Anders Stigebrandt and one anonymous referee.

\section{References}

Algar, C. K. and Vallino, J. J.: Predicting microbial nitrate reduction pathways in coastal sediments, Aquat. Microb. Ecol., 71, 223238, https://doi.org/10.3354/ame01678, 2014.

Algeo, T. J. and Ingall, E.: Sedimentary $\mathrm{C}_{\mathrm{org}}$ : $\mathrm{P}$ ratios, paleocean ventilation, and Phanerozoic atmospheric $\mathrm{pO}_{2}$, Palaeogeogr. Palaeoecol., 256, 130-155, https://doi.org/10.1016/j.palaeo.2007.02.029, 2007.

Almroth-Rosell, E., Edman, M., Eilola, K., Meier, H. E. M., and Sahlberg, J.: Modelling nutrient retention in the coastal zone of an eutrophic sea, Biogeosciences, 13, 5753-5769, https://doi.org/10.5194/bg-13-5753-2016, 2016.

An, S. and Gardner, W. S.: Dissimilatory nitrate reduction to ammonium (DNRA) as a nitrogen link, versus denitrification as a sink in a shallow estuary (Laguna Madre/Baffin Bay, Texas), Mar. Ecol. Prog. Ser., 237, 41-50, https://doi.org/10.3354/meps237041, 2002.

Anderson, D. M., Glibert, P. M., and Burkholder, J. M.: Harmful algal blooms and eutrophication: nutrient sources, composition, and consequences, Estuaries, 25, 704-726, https://doi.org/10.1007/BF02804901, 2002.

Andersen, J. H., Carstensen, J., Conley, D. J., Dromph, K., FlemingLehtinen, V., Gustafsson, B. G., Josefson, A. B., Norkko, A., Villnäs, A., and Murray, C.: Long-term temporal and spatial trends in eutrophication status of the Baltic Sea, Biol. Rev., 92, 135-149, https://doi.org/10.1111/brv.12221, 2017.

APHA: Standard methods for the examination of water and wastewater, 11 Edn., Am. J. Public Health, 51, 940, https://doi.org/10.2105/AJPH.51.6.940-a, 2005. 
Asmala, E., Carstensen, J., Conley, D. J., Slomp, C. P., Stadmark, J., and Voss, M.: Efficiency of the coastal filter: Nitrogen and phosphorus removal in the Baltic Sea, Limnol. Oceanogr., 62, 222-238, https://doi.org/10.1002/lno.10644, 2017.

Asmala, E., Carstensen, J., Conley, D. J., Slomp, C. P., Stadmark, J., and Voss, M.: A reply to the comment by Karlsson et al., Limnol. Oceanogr., 64, 1832-1833, https://doi.org/10.1002/lno.11195, 2019.

Berg, P., Risgaard-Petersen, N., and Rysgaard, S.: Interpretation of measured concentration profiles in sediment pore water, Limnol. Oceanogr., 43, 1500-1510, https://doi.org/10.4319/lo.1998.43.7.1500, 1998.

Boesch, D. F.: Challenges and opportunities for science in reducing nutrient over-enrichment of coastal ecosystems, Estuaries, 25, 886-900, https://doi.org/10.1007/BF02804914, 2002.

Bonaglia, S., Bartoli, M, Gunnarsson, J., Rahm, L., Raymond, C., Svensson, O., Shakeri Yekta, S., and Brüchert, V.: Effect of reoxygenation and Marenzelleria spp. Bioturbation on Baltic Sea sediment metabolism, Mar. Ecol. Prog. Ser., 482, 43-55, https://doi.org/10.3354/meps10232, 2013.

Bonaglia, S., Deutsch, B., Bartoli, M., Marchant, H. K., and Brüchert, V.: Seasonal oxygen, nitrogen and phosphorus benthic cycling along an impacted Baltic Sea estuary: regulation and spatial patterns, Biogeochemistry, 119, 139-160, https://doi.org/10.1007/s10533-014-9953-6, 2014.

Bonaglia, S., Hylén, A., Rattray, J. E., Kononets, M. Y., Ekeroth, N., Roos, P., Thamdrup, B., Brüchert, V., and Hall, P. O. J.: The fate of fixed nitrogen in marine sediments with low organic loading: an in situ study, Biogeosciences, 14, 285-300, https://doi.org/10.5194/bg-14-285-2017, 2017.

Bouwman, A. F., Bierkens, M. F. P., Griffioen, J., Hefting, M. M., Middelburg, J. J., Middelkoop, H., and Slomp, C. P.: Nutrient dynamics, transfer and retention along the aquatic continuum from land to ocean: towards integration of ecological and biogeochemical models, Biogeosciences, 10, 1-22, https://doi.org/10.5194/bg-10-1-2013, 2013.

Bower, C. E. and Holm-Hansen, T.: A salicylate-hypochlorite method for determining ammonia in seawater, Can. J. Fish. Aquat. Sci., 37, 794-798, https://doi.org/10.1139/f03-113, 1980.

Bryhn, A. C. and Håkanson, L.: Land uplift effects on the phosphorus cycle of the Baltic Sea, Environ. Earth Sci., 62, 1761-1770, https://doi.org/10.1007/s12665-010-0656-6, 2011.

Burgin, A. J. and Hamilton, S. K.: Have we overemphasized the role of denitrification in aquatic ecosystems? A review of nitrate removal pathways, Front. Ecol. Environ., 5, 89-96, https://doi.org/10.1890/15409295(2007)5[89:HWOTRO]2.0.CO;2, 2007.

Burton, E. D., Sullivan, L. A., Bush, R. T., Johnston, S. G., and Keene, A. F.: A simple and inexpensive chromium-reducible sulfur method for acid-sulfate soils, Appl. Geochem., 23, 27592766, https://doi.org/10.1016/j.apgeochem.2008.07.007, 2008.

Carman, R., Aigars, J., and Larsen, B.: Carbon and nutrient geochemistry of the surface sediments of the Gulf of Riga, Baltic Sea, Mar. Geol., 134, 57-76, https://doi.org/10.1016/00253227(96)00033-3, 1996.

Carstensen, J., Sánchez-Camacho, M., Duarte, C. M., Krause-Jensen, D., and Marba, N.: Connecting the dots: responses of coastal ecosystems to changing nutrient concentrations, Environ. Sci. Technol., 45, 9122-9132, https://doi.org/10.1021/es202351y, 2011.

Christensen, P. B., Rysgaard, S., Sloth, N. P., Dalsgaard, T., and Schwærter, S.: Sediment mineralization, nutrient fluxes, denitrification and dissimilatory nitrate reduction to ammonium in an estuarine fjord with sea cage trout farms, Aquat. Microb. Ecol., 21, 73-84, https://doi.org/10.3354/ame021073, 2000.

Claff, S. R., Sullivan, L. A., Burton, E. D., and Bush, R. T.: A sequential extraction procedure for acid sulfate soils: Partitioning of iron, Geoderma, 155, 224-230, https://doi.org/10.1016/j.geoderma.2009.12.002, 2010.

Cline, J. D.: Spectrophotometric determination of hydrogen sulfide in natural waters, Limnol. Oceanogr., 14, 454-458, https://doi.org/10.4319/lo.1969.14.3.0454, 1969.

Cloern, J. E.: Our evolving conceptual model of the coastal eutrophication problem, Mar. Ecol. Prog. Ser., 210, 223-253, https://doi.org/10.3354/meps210223, 2001.

Conley, D. J., Humborg, C., Rahm, L., Savchuk, O. P., and Wulff, F.: Hypoxia in the Baltic Sea and basin-scale changes in phosphorus biogeochemistry, Environ. Sci. Technol., 36, 5315-5320, https://doi.org/10.1021/es025763w, 2002.

Conley, D. J., Carstensen, J., Aigars, J., Are, P., Bonsdorff, E., Eremina, T., Haahti, B.-M., Humborg, C., Jonsson, P., Kotta, J., Lännegren, C., Larsson, U., Maximov, A., Medina, M. R., Lysiak-Pastuszak, E., Remekaite-Nikiene, N., Walve, J., Wilhelms, S., and Zillén, L.: Hypoxia increasing in the coastal zone of the Baltic Sea, Environ. Sci. Technol., 45, 6777-6783, https://doi.org/10.1021/es201212r, 2011.

Dalsgaard, T., Thamdrup, B., and Canfield, D. E.: Anaerobic ammonium oxidation (anammox) in the marine environment, Res. Microbiol., 156, 457-464, https://doi.org/10.1016/j.resmic.2005.01.011, 2005.

Dalsgaard, T., De Brabandere, L., and Hall, P. O.: Denitrification in the water column of the central Baltic Sea, Geochim. Cosmochim. Ac., 106, 247-260, https://doi.org/10.1016/j.gca.2012.12.038, 2013.

Diaz, R. J. and Rosenberg, R.: Spreading dead zones and consequences for marine ecosystems, Science, 321, 926-929, https://doi.org/10.1126/science.1156401, 2008.

Dijkstra, N., Kraal, P., Kuypers, M. M. M., Schnetger, B., and Slomp, C. P.: Are iron-phosphate minerals a sink for phosphorus in anoxic Black Sea sediments?, PLoS ONE, 9, 1-12, https://doi.org/10.1371/journal.pone.0101139, 2014.

Duarte, C. M., Conley, D. J., Carstensen, J., and SánchezCamacho, M.: Return to Neverland: shifting baselines affect eutrophication restoration targets, Estuar. Coast., 32, 29-36, https://doi.org/10.1007/s12237-008-9111-2, 2009.

Edman, M. K., Eilola, K., Almroth-Rosell, E., Meier, H. E., Wåhlström, I., and Arneborg, L.: Nutrient retention in the Swedish coastal zone, Front. Mar. Sci., 5, 415, https://doi.org/10.3389/fmars.2018.00415, 2018.

Egger, M., Jilbert, T., Behrends, T., Rivard, C., and Slomp, C. P.: Vivianite is a major sink for phosphorus in methanogenic coastal surface sediments, Geochim. Cosmochim. Ac., 169, 217-235, https://doi.org/10.1016/j.gca.2015.09.012, 2015.

Engqvist, A. and Andrejev, O.: Water exchange of the Stockholm archipelago - a cascade framework modelling approach, J. Sea Res., 49, 275-294, https://doi.org/10.1016/S13851101(03)00023-6, 2003. 
Füssel, J., Lam, P., Lavik, G., Jensen, M. M., Holtappels, M., Günter, M., and Kuypers, M. M. M.: Nitrite oxidation in the Namibian oxygen minimum zone, ISME J., 6, 1200-1209, https://doi.org/10.1038/ismej.2011.178, 2012.

Giblin, A. E., Tobias, C. R., Song, B., Weston, N., Banta, G. T., and Rivera-Monroy, V. H.: The importance of dissimilatory nitrate reduction to ammonium (DNRA) in the nitrogen cycle of coastal ecosystems, Oceanography, 26, 124-131, https://doi.org/10.5670/oceanog.2013.54, 2013.

Gidhagen, L.: Coastal upwelling in the Baltic Sea. Satellite and in situ measurements of sea surface temperatures indicating coastal upwelling, Estuar. Coast. Shelf S., 24, 449-462, https://doi.org/10.1016/0272-7714(87)90127-2, 1987.

Grasshoff, K., Kremling, K., and Ehrhardt, M.: Methods of Seawater Analysis, Wiley-VCH, Weinheim/Deerfield Beach, Florida, 600 pp., 1999.

Griffiths, J. R., Kadin, M., Nascimento, F. J. A., Tamelander, T., Törnroos, A., Bonaglia, S., Bonsdorff, E., Brüchert, V., Gårdmark, A., Järnström, M., Kotta, J., Lindegren, M., Nordström, M. C., Norkko, A., Olsson, J., Weigel, B., Žydelis, R., Blenckner, T., Niiranen, S., and Winder, M.: The importance of benthic-pelagic coupling formarine ecosystem functioning in a changing world, Glob. Change Biol., 23, 2179-2196, https://doi.org/10.1111/gcb.13642, 2017.

Gustafsson, B. G., Schenk, F., Blenckner, T., Eilola, K., Meier, H. E. M., Müller-Karulis, B., Neumann, T., Ruoho-Airola, T., Savchuk, O. P., and Zorita, E.: Reconstructing the development of Baltic Sea eutrophication 1850-2006, Ambio, 41, 534-548, https://doi.org/10.1007/s13280-012-0318-x, 2012.

Halpern, B. S., Walbridge, S., Selkoe, K. A., Kappel, C. V., Micheli, F., D’Agrosa, C., Bruno, J. F., Casey, K. S., Ebert, C., Fox, H. E., Fujita, R., Heinemann, D., Lenihan, H. S., Madin, E. M. P., Perry, M. T., Selig, E. R., Spalding, M., Steneck, R., and Watson, R.: A global map of human impact on marine ecosystems, Science, 319, 948-952, https://doi.org/10.1126/science.1149345, 2008.

Hansson, M., Viktorsson, L., and Andersson, L.: Oxygen survey in the Baltic Sea 2018 - Extent of anoxia and hypoxia, 1960-2018, SMHI, Report Oceanography No 65, 11 pp., 2019.

Hellemann, D., Tallberg, P., Bartl, B., Voss, M., and Hietanen, S.: Denitrification in an oligotrophic estuary: a delayed sink for rivering nitrate, Mar. Ecol. Prog. Ser., 583, 63-80, https://doi.org/10.3354/meps12359, 2017.

Hermans, M., Lenstra, W. K., van Helmond, N. A. G. M., Behrends, T., Egger, M., Séguret, M. J., Gustafsson, E., Gustafsson, B. G., and Slomp, C. P.: Impact of natural re-oxygenation on the sediment dynamics of manganese, iron and phosphorus in a euxinic Baltic Sea basin, Geochim. Cosmochim. Ac., 246, 174-196, https://doi.org/10.1016/j.gca.2018.11.033, 2019a.

Hermans, M., Lenstra, W. K., Hidalgo-Martinez, S., van Helmond, N. A. G. M., Witbaard, R., Meysman, F., Gonzalez, S., and Slomp, C. P.: Abundance and Biogeochemical Impact of Cable Bacteria in Baltic Sea Sediments, Environ. Sci. Technol., 53, 7494-7503, https://doi.org/10.1021/acs.est.9b01665, 2019b.

Hietanen, S., Laine, A. O., and Lukkari, K.,: The complex effects of the invasive polychaetes Marenzelleria spp. on benthic nutrient dynamics, J. Exp. Mar. Biol. Ecol., 352, 89-102, https://doi.org/10.1016/j.jembe.2007.07.018, 2007.

Hill, C. and Wallström, K.: Stockholm Archipelago, in: Ecology of Baltic Coastal Waters (Ecological Studies 197), edited by: Schiewer, U., Springer-Verlag, Berlin, Heidelberg, Germany, 309-334, 2008.

Jackson, J. B. C., Kirby, M. X., Berger, W. H., Bjorndal, K. A., Botsford, L. V., Bourque, B. J., Bradbury, R. H., Cooke, R., Erlandson, J., Estes, J. A., Hughes, T. P., Kidwell, S., Lange, C. B., Lenihan, H. S., Pandolfi, J. M., Peterson, C. H., Steneck, R. S., Tegner, M. J., and Warner, R. R.: Historical overfishing and the recent collapse of coastal ecosystems, Science, 293, 629-638, https://doi.org/10.1126/science.1059199, 2001.

Jäntti, H. and Hietanen, S.: The effects of hypoxia on sediment nitrogen cycling in the Baltic Sea, Ambio, 41, 161-169, https://doi.org/10.1007/s13280-011-0233-6, 2012.

Jäntti, H., Stange, F., Leskinen, E., and Hietanen, S.: Seasonal variation in nitrification and nitrate-reduction pathways in coastal sediments in the Gulf of Finland, Baltic Sea, Aquat. Microb. Ecol., 63, 171-181, https://doi.org/10.3354/ame01492, 2011.

Jensen, H. S., Mortensen, P. B., Andersen, F. O., Rasmussen, E., and Jensen, A.: Phosphorus cycling in a coastal marine sediment, Aarhus Bay, Denmark, Limnol. Oceanogr., 40, 908-917, https://doi.org/10.4319/lo.1995.40.5.0908, 1995.

Johansson, L. and Wallström, K.: Urban impact in the history of water quality in the Stockholm archipelago, Ambio, 30, 277-281, https://doi.org/10.1579/0044-7447-30.4.277, 2001.

Jonsson, P., Carman, R., and Wulff, F.: Laminated Sediments in the Baltic: A Tool for Evaluating Nutrient Mass Balances, Ambio, 19, 152-158, 1990.

Josefson, A. and Rasmussen, B.: Nutrient retention by benthic macrofaunal biomass of Danish estuaries: Importance of nutrient load and residence time, Estuar. Coast. Shelf Sci., 50, 205-216, https://doi.org/10.1006/ecss.1999.0562, 2000.

Karlsson, O. M., Jonsson, P. O., Lindgren, D., Malmaeus, J. M., and Stehn, A.: Indications of recovery from hypoxia in the inner Stockholm archipelago, Ambio, 39, 486-495, https://doi.org/10.1007/s13280-010-0079-3, 2010.

Karlsson, O. M., Bryhn, A. C., Håkanson, L., Hållén, J., Jonsson, P., Malmaeus, J. M., and Rydin, E.: On the role of sedimentological processes controlling phosphorus burial in the coastal zone of the Baltic Sea, Limnol. Oceanogr., 64, 1828-1831, https://doi.org/10.1002/lno.11194, 2019.

Kemp, W. M., Testa, J. M., Conley, D. J., Gilbert, D., and Hagy, J. D.: Temporal responses of coastal hypoxia to nutrient loading and physical controls, Biogeosciences, 6, 2985-3008, https://doi.org/10.5194/bg-6-2985-2009, 2009.

Kessler, A. J., Roberts, K. L., Bissett, A., and Cook, P. L.: Biogeochemical controls on the relative importance of denitrification and dissimilatory nitrate reduction to ammonium in estuaries, Global Biogeochem. Cy., 32, 1045-1057, https://doi.org/10.1029/2018GB005908, 2018.

Kraal, P., Dijkstra, N., Behrends, T., and Slomp, C. P.: Phosphorus burial in sediments of the sulfidic deep Black Sea: Key roles for adsorption by calcium carbonate and apatite authigenesis, Geochim. Cosmochim. Ac., 204, 140-158, https://doi.org/10.1016/j.gca.2017.01.042, 2017.

Kraft, B., Tegetmeyer, H. E., Sharma, R., Klotz, M. G., Ferdelman, T. G., Hettich, R. L., Geelhoed, J. S., and Strous, M.: The environmental controls that govern the end product of bacterial nitrate respiration, Science, 345, 676-679, https://doi.org/10.1126/science.1254070, 2014. 
Krause-Jensen, D. and Duarte, C. M.: Substantial role of macroalgae in marine carbon sequestration, Nat. Geosci., 9, 737-742, https://doi.org/10.1038/ngeo2790, 2016.

Laverock, B., Gilbert, J., Tait, K., Osborn, A. M., and Widdicombe, S.: Bioturbation: impact on the marine nitrogen cycle, Biochem. Soc. Trans., 39, 315-320, https://doi.org/10.1042/BST0390315, 2011.

Lenstra, W. K., Egger, M., van Helmond, N. A. G. M., Kritzberg, E., Conley, D. J., and Slomp, C. P.: Large variations in iron input to an oligotrophic Baltic Sea estuary: impact on sedimentary phosphorus burial, Biogeosciences, 15, 6979-6996, https://doi.org/10.5194/bg-15-6979-2018, 2018.

Lindh, G.: Miljörapport 2013, Stockholm Vatten VA AB, Stockholm Vatten, 87 pp., 2013.

Lukkari, K., Leivuori, M., and Kotilainen, A.: The chemical character and behaviour of phosphorus in poorly oxygenated sediments from open sea to organic-rich inner bay in the Baltic Sea, Biogeochemistry, 96, 25-48, https://doi.org/10.1007/s10533-009-93437, 2009.

McGlathery, K. J., Sundbäck, K., and Anderson, I. C.: Eutrophication in shallow coastal bays and lagoons: The role of plants in the coastal filter, Mar. Ecol. Prog. Ser., 348, 1-18, https://doi.org/10.3354/meps07132, 2007.

Mort, H. P., Slomp C. P., Gustafsson B. G., and Andersen, T. J.: Phosphorus recycling and burial in Baltic Sea sediments with contrasting redox conditions, Geochim. Cosmochim. Ac., 74, 1350-1362, https://doi.org/10.1016/j.gca.2009.11.016, 2010.

Nembrini, G. P., Capobianco, J. A., Viel, M., and Williams, A. F.: A Mössbauer and chemical study of the formation of vivianite in sediments of Lago Maggiore (Italy), Geochim. Cosmochim. Ac., 47, 1459-1464, https://doi.org/10.1016/0016-7037(83)90304-6, 1983.

Nielsen, L. P.: Denitrification in sediment determined from nitrogen isotope pairing, FEMS Microbiol. Ecol., 9, 357-361, https://doi.org/10.1111/j.1574-6968.1992.tb04828.x, 1992.

Ning, W., Ghosh, A., Jilbert, T., Slomp, C. P., Khan, M., Nyberg, J., Conley, D. J., and Filipsson, H. L.: Evolving coastal character of a Baltic Sea inlet during the Holocene shoreline regression: impact on coastal zone hypoxia, J. Paleolimnol., 55, 319-338, https://doi.org/10.1007/s10933-016-9882-6, 2016.

Nixon, S. W., Ammerman, J. W., Atkinson, L. P., Berounsky, V. M., Billen, G., Boicourt, W. C., Boynton, W. R., Church T. M., Ditoro D. M., Elmgren, R., Garber J. H., Giblin, A. E., Jahnke, R. A., Owens N. J. P., Pilson M. E. Q., and Seitzinger, S. P.: The fate of nitrogen and phosphorus at the land sea margin of the North Atlantic Ocean, Biogeochemistry, 35, 141-180, https://doi.org/10.1007/BF02179826, 1996.

Nizzoli, D., Carraro, E., Nigro, V., and Viaroli, P.: Effect of organic enrichment and thermal regime on denitrification and dissimilatory nitrate reduction to ammonium (DNRA) in hypolimnetic sediments of two lowland lakes, Water Res., 44, 2715-2724, https://doi.org/10.1016/j.watres.2010.02.002, 2010.

Norkko, J., Reed, D. C., Timmermann, K., Norkko, A., Gustafsson, B. G., Bonsdorff, E., Slomp, C. P., Carstensen, J., and Conley, D. J.: A welcome can of worms?, Hypoxia mitigation by an invasive species, Glob. Change Biol. 18, 422-434, https://doi.org/10.1111/j.1365-2486.2011.02513.x, 2012.
Paerl, H. W. and Otten, T. G.: Harmful cyanobacterial blooms: causes, consequences, and controls, Microb. Ecol., 65, 9951010, https://doi.org/10.1007/s00248-012-0159-y, 2013.

Pelegri, S. P. and Blackburn, T. H.: Effect of bioturbation by Nereis sp., Mya arenaria and Cerastoderma sp. on nitrification and denitrification in estuarine sediments, Ophelia, 42, 289-299, https://doi.org/10.1080/00785326.1995.10431509, 1995.

Piña-Ochoa, E. and Álvarez-Cobelas, M.: Denitrification in aquatic environments: A cross-system analysis, Biogeochemistry, 81, 111-130, https://doi.org/10.1007/s10533-006-9033-7, 2006.

Poulton, S. W. and Canfield, D. E.: Development of a sequential extraction procedure for iron: Implications for iron partitioning in continentally derived particulates, Chem. Geol., 214, 209-221, https://doi.org/10.1016/j.chemgeo.2004.09.003, 2005.

Rabalais, N. N., Turner, R. E., Diaz, R. J., and Justić, D.: Global change and eutrophication of coastal waters, ICES J. Mar. Sci., 66, 1528-1537, https://doi.org/10.1093/icesjms/fsp047, 2009.

Rabalais, N. N., Díaz, R. J., Levin, L. A., Turner, R. E., Gilbert, D., and Zhang, J.: Dynamics and distribution of natural and human-caused hypoxia, Biogeosciences, 7, 585-619, https://doi.org/10.5194/bg-7-585-2010, 2010.

Reed, D. C., Slomp, C. P., and Gustafsson, B. G.: Sedimentary phosphorus dynamics and the evolution of bottom-water hypoxia: A coupled benthic-pelagic model of a coastal system, Limnol. Oceanogr., 56, 1075-1092, https://doi.org/10.4319/lo.2011.56.3.1075, 2011.

Risgaard-Petersen, N., Revsbech, N. P., and Rysgaard, S.: Combined microdiffusion-hypobromite oxidation method for determining nitrogen-15 isotope in ammonium, Soil Sci. Soc. Am. J., 59, 1077-1080, https://doi.org/10.2136/sssaj1995.03615995005900040018x, 1995.

Risgaard-Petersen, N., Nielsen, L. P., Rysgaard, S., Dalsgaard, T., and Meyer, R. L.: Application of the isotope pairing technique in sediments where anammox and denitrification coexist, Limn. Oceanog.-Meth., 1, 63-73, https://doi.org/10.4319/lom.2003.1.63, 2003.

Robertson, E. K., Bartoli, M., Brüchert, V., Dalsgaard, T., Hall, P. O. J., Hellemann, D., Hietanen, S., Zilius, M., and Conley, D. J.: Application of the isotope pairing technique in sediments: use, challenges and new directions, Limnol. Oceanogr.-Meth., 17, 112 136, https://doi.org/10.1002/lom3.10303, 2019.

Ruttenberg, K. C.: Development of a sequential extraction method for different forms of phosphorus in marine sediments, Limnol. Oceanogr., 37, 1460-1482, https://doi.org/10.4319/lo.1992.37.7.1460, 1992.

Ruttenberg, K. C. and Berner, R.A.: Authigenic apatite formation and burial in sediments from non-upwelling, continental margin environments, Geochim. Cosmochim. Ac., 57, 991-1007, https://doi.org/10.1016/0016-7037(93)90035-U, 1993.

Rydin, E. and Kumblad, L.: Capturing past eutrophication in coastal sediments - Towards water-quality goals, Estuar. Coast. Shelf Sci., 221, 184-188, https://doi.org/10.1016/j.ecss.2019.02.046, 2019.

Rydin, E., Malmaeus, M., Karlsson, M., and Jonsson, P.: Phosphorus release from coastal Baltic Sea sediments as estimated from sediment profiles, Estuar. Coast Shelf Sci., 92, 111-117, https://doi.org/10.1016/j.ecss.2010.12.020, 2011. 
Savchuk, O. P.: Resolving the Baltic Sea into seven subbasins: $\mathrm{N}$ and P budgets for 1991-1999, J. Mar. Syst., 56, 1-15, https://doi.org/10.1016/j.jmarsys.2004.08.005, 2005.

Schnetger, B. and Lehners, C.: Determination of nitrate plus nitrite in small volume marine water samples using vanadium (III) chloride as a reduction agent, Mar. Chem., 160, 91-98, https://doi.org/10.1016/j.marchem.2014.01.010, 2014.

Schulz, H. D.: Quantification of Early Diagenesis: Dissolved Constituents in Pore Water and Signals in the Solid Phase, edited by: Schulz, H. D. and Zabel, M., 2nd Edn., Springer-Verlag, Berlin, Heidelberg, Germany, Mar. Chem., 73-124, 2006.

Seitzinger, S.: Denitrification in freshwater and coastal marine ecosystems: Ecological and geochemical significance, Limnol. Oceanogr., 33, 702-724, https://doi.org/10.4319/lo.1988.33.4part2.0702, 1988.

Seitzinger, S.: Denitrification in aquatic sediments, in: Denitrification in Soil and Sediment, edited by: Revsbech, N. P., Sørensen, J., Plenum Press, New York, USA, 301-322, 1990.

Seitzinger, S., Harrison, J. A., Böhlke, J. K., Bouwman, A. F., Lowrance, R., Peterson, B., Tobias, C., and van Drecht, G.: Denitrification across landscapes and waterscapes: a synthesis, Ecol. Appl., 6, 2064-2090, https://doi.org/10.1890/10510761(2006)016[2064:DALAWA]2.0.CO;2, 2006.

Silvennoinen, H., Hietanen, S., Liikanen, A., Stange, C. F., Russow, R., Kuparinen, J., and Martikainen, P. J.: Denitrification in the river estuaries of the northern Baltic Sea, Ambio, 134-140, https://doi.org/10.1579/00447447(2007)36[134:DITREO]2.0.CO;2, 2007.

Slomp, C. P.: Phosphorus cycling in the estuarine and coastal zones: Sources, sinks, and Transformations, in: Treatise on estuarine and coastal science, Vol. 5, edited by: Wolanski, E., McLusky, D. S., Academic Press, Waltham, 201-229, 2011.

Slomp, C. P., Van der Gaast, S., and Van Raaphorst, W.: Phosphorus binding by poorly crystalline iron oxides in North Sea sediments, Mar. Chem., 52, 55-73, https://doi.org/10.1016/03044203(95)00078-X, 1996.

Slomp, C. P., Mort, H. P., Jilbert, T., Reed, D. C., Gustafsson, B. G., and Wolthers, M.: Coupled dynamics of iron and phosphorus in sediments of an oligotrophic coastal basin and the impact of anaerobic oxidation of methane, PLoS ONE, 8, e62386, https://doi.org/10.1371/journal.pone.0062386, 2013.

SMHI: Water chemistry data 1968-2017, Swedish Meteorological and Hydrological Institute, available at: http://www.smhi.se/klimatdata/oceanografi/havsmiljodata/ marina-miljoovervakningsdata, or on request from shark@smhi.se, last access: 10 April 2019.

Smith, V. H.: Eutrophication of freshwater and coastal marine ecosystems a global problem, Environ. Sci. Pollut. R., 10, 126139, https://doi.org/10.1065/espr2002.12.142, 2003.

Soetaert, K. and Herman, P. M. J.: A practical guide to ecological modelling: using R as a simulation platform, Springer Science \& Business Media, 372 pp., 2009.

Song, G. D., Liu, S. M., Marchant, H., Kuypers, M. M. M., and Lavik, G.: Anammox, denitrification and dissimilatory nitrate reduction to ammonium in the East China Sea sediment, Biogeosciences, 10, 6851-6864, https://doi.org/10.5194/bg-106851-2013, 2013.
Song, G. D., Liu, S. M., Kuypers, M. M. M., and Lavik, G.: Application of the isotope pairing technique in sediments where anammox, denitrification, and dissimilatory nitrate reduction to ammonium coexist, Limnol. Oceanogr.-Meth, 14, 801-815, https://doi.org/10.1002/lom3.10127, 2016.

Stigebrandt, A., Liljebladh, B., de Brabandere, L., Forth, M., Granmo, Å., Hall, P., Hammar, J., Hansson, D., Kononets, M., Magnusson, M., Norén, F., Rahm, L., Treusch, A. H., and Viktorsson, L.: An experiment with forced oxygenation of the deepwater of the anoxic by Fjord, Western Sweden, Ambio, 44, 4254, https://doi.org/10.1007/s13280-014-0524-9, 2015.

Strickland, J. D. H. and Parsons, T. R.: A Practical Handbook of Seawater Analysis, Fisheries Research Board of Canada, Ottawa, 55, 167, https://doi.org/10.1002/iroh.19700550118, 1972.

Sulu-Gambari, F., Hagens, M., Behrends, T., Seitaj, D., Meysman, F. J., Middelburg, J., and Slomp, C. P.: Phosphorus cycling and burial in sediments of a seasonally hypoxic marine basin, Estuar. Coast., 41, 921-939, https://doi.org/10.1007/s12237-017-0324$0,2018$.

Thamdrup, B.: New Pathways and processes in the global nitrogen cycle, Annu. Rev. Ecol. Evol. S., 43, 407-428, https://doi.org/10.1146/annurev-ecolsys-102710-145048, 2012.

Turner, R. E., Rabalais, N. N., and Justic, D.: Gulf of Mexico hypoxia: Alternate states and a legacy, Environ. Sci. Technol., 42, 2323-2327, https://doi.org/10.1021/es071617k, 2008.

Van Cappellen, P. and Ingall, E. D.: Benthic phosphorus regeneration, net primary production, and ocean anoxia: a model of the coupled marine biogeochemical cycles of carbon and phosphorus, Paleoceanography, 9, 677-692, https://doi.org/10.1029/94PA01455, 1994.

Van den Berg, L. J., Jones, L., Sheppard, L. J., Smart, S. M., Bobbink, R., Dise, N. B., and Ashmore, M. R.: Evidence for differential effects of reduced and oxidised nitrogen deposition on vegetation independent of nitrogen load, Environ. Pollut., 208, 890-897, https://doi.org/10.1016/j.envpol.2015.09.017, 2016.

Van Helmond, N. A. G. M., Jilbert, T., and Slomp, C. P.: Hypoxia in the Holocene Baltic Sea: Comparing modern versus past intervals using sedimentary trace metals, Chem. Geol., 493, 478-490, https://doi.org/10.1016/j.chemgeo.2018.06.028, 2018.

Van Helmond, N. A. G. M., Lougheed, B. C., Vollebregt, A., Peterse, F., Fontorbe, G., Conley, D. J., and Slomp, C. P.: Recovery from multi-millennial natural coastal hypoxia in the Baltic Sea (Stockholm Archipelago) terminated by modern human activity, Limnol. Oceanogr., in review, 2020.

Voss, M., Baker, A., Bange, H. W., Conley, D., Cornell, S., Deutsch, B., Engel, A., Ganeshram, R., Garnier, J., Heiskanen, A. S., Jickells, T., Lancelot, C., Mcquatters-Gollop, A., Middelburg, J., Schiedek, D., Slomp, C. P., and Conley, D. P.: Nitrogen processes in coastal and marine ecosystems, in: The European Nitrogen Assessment, edited by: Sutton, M. A., Howard, C. M., Erisman, J. W., Billen, G., Bleeker, A., Grennfelt, P., van Grinsven, H., Grizzetti, B., Cambridge University Press, New York, USA, 147176, 2011.

Walve, J., Sandberg, M., Larsson, U., and Lännergren, C.: A Baltic Sea estuary as a phosphorus source and sink after drastic load reduction: seasonal and long-term mass balances for the Stockholm inner archipelago for 1968-2015, Biogeosciences, 15, 30033025, https://doi.org/10.5194/bg-15-3003-2018, 2018. 